\title{
Investigating three patterns of new particles growing to the size of cloud condensation nuclei in Beijing's urban atmosphere
}

\author{
Liya Ma ${ }^{1, \star}$, Yujiao Zhu ${ }^{1,2} \star$, Mei Zheng ${ }^{3}$, Yele Sun ${ }^{4}$, Lei Huang ${ }^{1}$, Xiaohuan Liu ${ }^{1}$, Yang Gao ${ }^{1}$, Yanjie Shen ${ }^{1}$, \\ Huiwang Gao ${ }^{1,5}$, and Xiaohong Yao ${ }^{1,5}$ \\ ${ }^{1}$ Laboratory of Marine Environmental Science and Ecology, Ministry of Education, \\ Ocean University of China, Qingdao 266100, China \\ ${ }^{2}$ Environment Research Institute, Shandong University, Qingdao 266237, China \\ ${ }^{3}$ State Key Joint Laboratory for Environmental Simulation and Pollution Control, College of Environmental Sciences and \\ Engineering, Peking University, Beijing 100871, China \\ ${ }^{4}$ State Key Laboratory of Atmospheric Boundary Layer Physics and Atmospheric Chemistry, Institute of Atmospheric \\ Physics, Chinese Academy of Sciences, Beijing 100029, China \\ ${ }^{5}$ Laboratory for Marine Ecology and Environmental Sciences, Qingdao National Laboratory for Marine Science and \\ Technology, Qingdao 266237, China \\ These authors contributed equally to this work.
}

Correspondence: Xiaohong Yao (xhyao@ouc.edu.cn) and Yujiao Zhu (zhuyujiao@sdu.edu.cn)

Received: 16 December 2019 - Discussion started: 4 May 2020

Revised: 5 November 2020 - Accepted: 10 November 2020 - Published: 11 January 2021

\begin{abstract}
The growth of newly formed particles with diameters from $\sim 10 \mathrm{~nm}$ to larger sizes was investigated in Beijing's urban atmosphere during 10-23 December 2011, 12-27 April 2012, and June-August 2014. In 11 out of 27 new particle formation (NPF) events during June-August, the maximum geometric median diameter $\left(D_{\text {pgmax }}\right)$ of newly formed particles exceeded $75 \mathrm{~nm}$, and the grown new particles may contribute to the population of cloud condensation nuclei. In contrast, no apparent growth in new particles with $D_{\text {pgmax }}<20 \mathrm{~nm}$ was observed in all of the events in December, in approximately half of the NPF events in April, and in only two events during June-August. New particles observed in the latter NPF events were too small to be activated as cloud condensation nuclei. Apparent new particle growth with $D_{\text {pgmax }} \leq 50 \mathrm{~nm}$ was observed in the remaining $18 \mathrm{NPF}$ events. The $11 \mathrm{NPF}$ events during June-August with $D_{\text {pgmax }}$ exceeding $75 \mathrm{~nm}$ were analyzed in detail. The particle growth patterns can be clearly classified into three types: one-stage growth and two-stage growth-A and growth-B patterns. The one-stage growth pattern is characterized by a continuous increase in $D_{\text {pg }}$ with $D_{\text {pgmax }} \geq 80 \mathrm{~nm}$ (4 out of $11 \mathrm{NPF}$ events), and the two-stage growth-A and growth-B patterns are characterized by no apparent growth and shrinkage of particles,
\end{abstract}

respectively, in the middle $2-4 \mathrm{~h}$ of the growth period ( 7 out of $11 \mathrm{NPF}$ events). Combining the observations of gaseous pollutants and measured (or modeled) concentrations of particulate chemical species, the three growth patterns were discussed in terms of the spatial heterogeneity of NPF, formation of secondary aerosols, and evaporation of semivolatile particulates. Secondary organic species and $\mathrm{NH}_{4} \mathrm{NO}_{3}$ were argued to be two major contributors to the growth of new particles, but $\mathrm{NH}_{4} \mathrm{NO}_{3}$ likely contributed to growth only in the late afternoon and/or at nighttime.

\section{Introduction}

Atmospheric aerosol particles can be derived either from primary emissions, including various natural and anthropogenic sources, or from secondary sources (Yao et al., 2005; Sabaliauskas et al., 2012; Vu et al., 2015; Seinfeld and Pandis, 2012; Quan et al., 2017; Zhu et al., 2019). Secondary sources are mainly related to atmospheric nucleation, followed by the growth of newly formed particles from $\sim 1 \mathrm{~nm}$ to larger sizes; this phenomenon is conventionally referred to as a new particle formation (NPF) event (Kulmala et al., 2004; Kermi- 
nen et al., 2018). In recent decades, numerous studies have been conducted on NPF, including field measurements in various atmospheres, laboratory studies on nucleation and initial growth in newly formed particles, regional-scale modeling of NPF and its impacts on climate, and development of new techniques for analyzing the chemical components of nanoparticles and their gaseous precursors. Building on the results of these studies, many review papers have summarized the state-of-the-art progress and noted challenges for future studies (Kulmala et al., 2004, 2012, 2016; Kulmala and Kerminen, 2008; Zhang et al., 2012, 2015; Kerminen et al., 2018; Chu et al., 2019; Lee et al., 2019).

Several studies have investigated the potential climate impacts of NPF events; for example, $10 \%$ to $60 \%$ of NPF events have been reported to yield an appreciable contribution to cloud condensation nuclei (CCN) (Kuang et al., 2009; Asmi et al., 2011; Laakso et al., 2013; Yu et al., 2014; Rose et al., 2017; Kerminen et al., 2018). Modeling studies have also proposed that approximately $50 \%$ of the $\mathrm{CCN}$ population is attributable to NPF events in the troposphere (Yu and Luo, 2009; Yu et al., 2014; Gordon et al., 2017). Nevertheless, reported observations have also shown that newly formed particles with diameters less than $40-50 \mathrm{~nm}$ can be activated as $\mathrm{CCN}$ only under high supersaturation (SS), such as $>0.6 \%$ (Li et al., 2015; Ma et al., 2016). When newly formed particles grow to a geometric median diameter of larger than $70 \mathrm{~nm}$, they significantly contribute to the $\mathrm{CCN}$ population at $\mathrm{SS} \leq 0.2 \%$ (Wiedensohler et al., 2009; Yue et al., 2011; Li et al., 2015; Ma et al., 2016; Zhu et al., 2019). In addition, field observations have also shown that in most NPF events, the maximum geometric median diameter $\left(D_{\text {pgmax }}\right)$ of newly grown particles is less than $40-50 \mathrm{~nm}$ before new particle signals drop to a negligible level (Zhu et al., 2014, 2017; Liu et al., 2014; Man et al., 2015; Yu et al., 2019). Thus, it is important to characterize NPF events, based on the $D_{\text {pgmax }}$ of grown new particles, and to explore the chemicals driving the growth of newly formed particles with $D_{\text {pgmax }}$ greater than $70 \mathrm{~nm}$.

With distinctive particle growth patterns being widely reported, Beijing is an ideal area for studying the growth of newly formed particles (Wehner et al., 2004; Wu et al., 2007, 2016; Wiedensohler et al., 2009; Yue et al., 2010; Matsui et al., 2011; Wang et al., 2013; Guo et al., 2014, 2020; Du et al., 2017; Zhu et al., 2017; Brean et al., 2019; Chen et al., 2019). For instance, as the first study of NPF events in Beijing, Wehner et al. (2004) reported a small growth rate $\left(\sim 1 \mathrm{~nm} \mathrm{~h}^{-1}\right)$ of newly formed particles during $25 \mathrm{~d}$ from 5 March to 18 April 2004. Such small growth rates are unlikely to facilitate the growth of particles to reach $\mathrm{CCN}$ sizes prior to removal from ambient air because of the large coagulation loss in Beijing (Kulmala and Kerminen, 2008; Kulmala et al., 2016; Chu et al., 2019; Guo et al., 2020). Similar to this finding, no apparent growth of newly formed particles with the $D_{\text {pgmax }}$ of approximately $10 \mathrm{~nm}$ always occurred in December 2011 at the same campus in Beijing (Zhu et al.,
2017). In contrast, the growth of newly formed particles to $\mathrm{CCN}$ size and even larger has also been observed in Beijing (Wu et al., 2007, 2016; Wiedensohler et al., 2009; Yue et al., 2010; Wang et al., 2013; Guo et al., 2014). The patterns of particle growth have not been well characterized. For example, the occurrence frequency of NPF events in which newly formed particles can grow to CCN size is virtually unknown. The same can be said to season trends in the occurrence frequency. Nevertheless, sulfuric acid and/or organic vapors have been proposed to drive particle growth in different NPF events (Wiedensohler et al., 2009; Yue et al., 2010; Wu et al., 2016). Recently, the formation of $\mathrm{NH}_{4} \mathrm{NO}_{3}$ has been proposed as a driver of the rapid growth of newly formed particles in field studies and chamber experiments (Zhu et al., 2014; Man et al., 2015; Wang et al., 2020). The role of $\mathrm{NH}_{4} \mathrm{NO}_{3}$ in the growth of newly formed particles in Beijing remains poorly understood. The contributions of sulfuric acid, organic vapors, and $\mathrm{NH}_{4} \mathrm{NO}_{3}$ to the growth of newly formed particles at different sizes are also nonexistent. Matsui et al. (2011) and Chen et al. (2019) simulated NPF and the growth of newly formed particles based on observations, but the modeling results were explained with large uncertainties.

In this study, we investigated NPF events in Beijing using observational data from three campaigns. We characterized NPF events according to the observed $D_{\text {pgmax }}$ of newly formed particles and then focused on analyzing the growth patterns of newly formed particles with a diameter from $\sim 10 \mathrm{~nm}$ to a larger size, paying particular attention to NPF events in which the $D_{\text {pgmax }}$ exceeded $70 \mathrm{~nm}$. We combined observations of gaseous pollutants and observed (or modeled) concentrations of organic matter (or secondary organic aerosol, $\mathrm{SOA}$ ), $\mathrm{NO}_{3}^{-}$, and $\mathrm{NH}_{4}^{+}$to identify the chemicals driving the growth of new particles, for example, varying major contributors in different growth periods. The survival probability of newly formed particles, which can grow over 50 or $70 \mathrm{~nm}$ (two CCN threshold sizes under different SS), was also estimated. Our study provides new insight into the growth of newly formed particles to larger sizes, as required for these particles to be activated as CCN at normal SS in the atmosphere.

\section{Methods}

\subsection{Sampling periods, sites, and instruments}

Two sampling sites were adopted to measure the particle number concentration spectra in Beijing. One is a rooftop site on the roof of an academic building within the campus

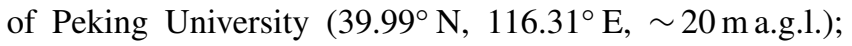
the other is a street site along a road located approximately $200 \mathrm{~m}$ from the rooftop site (Fig. 1). At the rooftop site, measurements were taken on 16-23 December 2011, 1227 April 2012, and 1 June-31 August 2014. At the street site, 


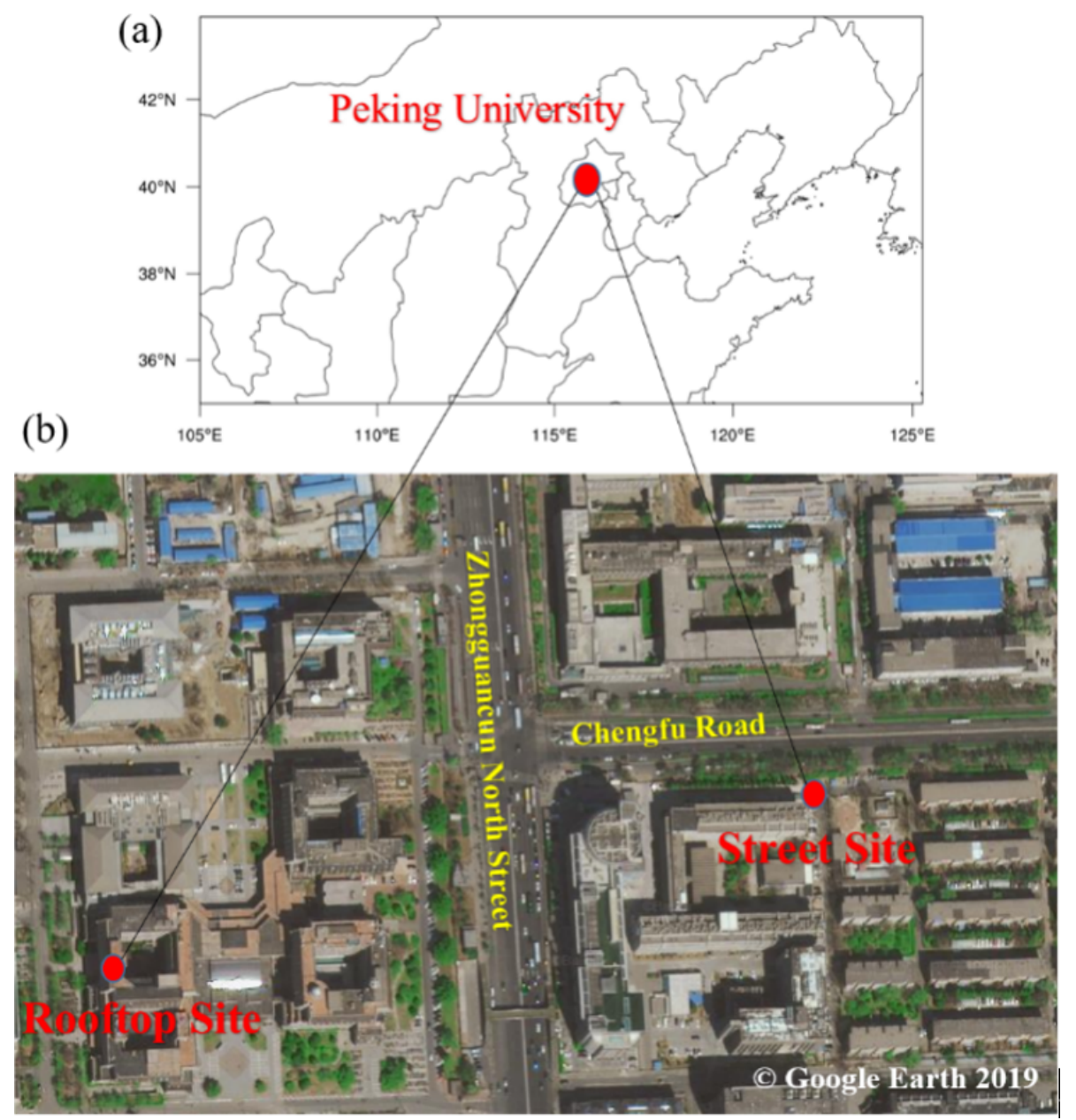

Figure 1. Locations of sampling sites (a) and satellite imagery of the two sampling sites (b) (downloaded from https://www.earthol.com/, last access: 23 December 2020).

measurements were taken on 10-23 December 2011 and 1827 April 2012. The concentrations of atmospheric particles were measured using a fast mobility particle sizer (FMPS, TSI model 3091) downstream of a dryer (TSI model 3062) at a $1 \mathrm{~s}$ time resolution in each measurement campaign. The FMPS was a paralleling particle sizer and reported number size distributions of aerosol particles from 5.6 to $560 \mathrm{~nm}$. In this study, the empirical correction procedure for FMPS size distribution data proposed by Zimmerman et al. (2015) was used for correction. The scaling-down coefficient of the total particle number concentration measured by the FMPS (1.28) was obtained through a correlation analysis of sideby-side measurements made by the FMPS and a condensation particle counter (CPC). A $\mathrm{SO}_{2}$ analyzer (Thermo model $43 \mathrm{i}$ ), an $\mathrm{O}_{3}$ analyzer (Thermo model $49 \mathrm{i}$ ), a $\mathrm{NO}_{x}$ analyzer (Thermo model 42i), and a meteorological monitoring system were operated at a $1 \mathrm{~min}$ resolution to obtain real-time observational data of gases and meteorological parameters on the rooftop site close to the FMPS in 2011, 2012, and before 10 July 2014. During the other observational periods
(11 July-31 August 2014), the mixing ratios of air pollutants at a $1 \mathrm{~h}$ resolution and meteorological data at a $3 \mathrm{~h}$ resolution were taken from the Wanliu air quality monitoring station in Haidian district $\left(39.99^{\circ} \mathrm{N}, 116.32^{\circ} \mathrm{E}\right.$; http://106.37.208.233: 20035/, last access: 20 October 2020) and the Beijing 54511 station $\left(39.95^{\circ} \mathrm{N}, 116.30^{\circ} \mathrm{E}\right.$; https://rp5.ru/, last access: 23 December 2020), respectively. The concentrations of oxygenated organic aerosols (OOAs) and inorganic species including $\mathrm{NO}_{3}^{-}, \mathrm{SO}_{4}^{2-}$, and $\mathrm{NH}_{4}^{+}$in $\mathrm{PM}_{1.0}$, during the period from 3 June to 11 July 2014, previously reported by Xu et al. (2017), were also used to facilitate the analysis. The data were measured using a high-resolution time-of-flight aerosol mass spectrometer (HR-ToF-AMS) at a $10 \mathrm{~min}$ resolution. The chemical composition of $\mathrm{PM}_{1.0}$ measured by the AMS has been widely used to interpret NPF events in the literature (Wiedensohler et al., 2009; Zhang et al., 2014; Man et al., 2015; Du et al., 2017; Rodelas et al., 2019; Kanawade et al., 2020) and was also used in this study. Low loadings of particulate chemical species in nanometer size ranges do not facilitate accurate measurement of their concentrations therein. 
However, the chemical composition of nanometer particles may differ from those of $\mathrm{PM}_{1.0}$ (Ehn et al., 2014; Wu et al., 2016). Moreover, the sampling site of the HR-ToF-AMS was located at the Tower Branch of the Institute of Atmospheric Physics in Beijing, China $\left(39.98^{\circ} \mathrm{N}, 116.38^{\circ} \mathrm{E}\right)$ and approximately $8 \mathrm{~km}$ away from Peking University. During NPF events at wind speeds of $4-6 \mathrm{~m} \mathrm{~s}^{-1}$, a $0.5 \mathrm{~h}$ delay may occur for air parcels sweeping from one site with the FMPS deployed to another site with the AMS deployed. For NPF events with durations over several hours, the events were expected to occur regionally (Kerminen et al., 2018; Chu et al., 2019). Thus, it is reasonable to interpret the cumulative growth of newly formed particles within several hours, measured by the FMPS, by using the net simultaneous change in concentrations of chemical species, measured by the AMS. Additionally, $\mathrm{He}$ et al. (2001) reported that the chemical composition of $\mathrm{PM}_{2.5}$ was reasonably homogeneous in the two sampling site zones.

\subsection{Computational methods}

NPF events were identified according to the definition by Dal Maso et al. (2005), and only NPF events with durations over $1 \mathrm{~h}$ were analyzed in this study. The local standard time was used to describe the NPF events in this study. In each NPF event, the net maximum increase in the nucleation mode particle number concentration (NMINP) was calculated according to Zhu et al. (2017). The nucleation mode was defined from 8 to $20 \mathrm{~nm}$ in this study.

$\mathrm{NMINP}=N_{8-20 \mathrm{~nm}}\left(t_{1}\right)-N_{8-20 \mathrm{~nm}}\left(t_{0}\right)$

$N_{8-20 \mathrm{~nm}}$ represents the sum of particle number concentrations with diameters from 8 to $20 \mathrm{~nm} ; t_{0}$ and $t_{1}$ represent the time of the initial observation of an NPF event and the time at which $N_{8-20 \mathrm{~nm}}$ arrives at the maximum value, respectively. Note that a few spikes of several minutes were occasionally observed and were excluded in the calculation of NMINP because they may reflect primary particles from localized sources (Liu et al., 2014; Zhu et al., 2017).

The growth rate (GR) and shrinkage rate (SR) of new particles are determined by the slope of the fitted geometric median diameter of new particles $\left(D_{\mathrm{pg}}\right)$ over time (Whitby, 1978; Yao et al., 2010; Zhu et al., 2014; Man et al., 2015). In an NPF event or in each growth period of one NPF event, the maximum value of $D_{\mathrm{pg}}$ is defined as $D_{\text {pgmax }}$. Again, a few occasional spikes of several minutes were excluded to calculate GR, SR, and $D_{\text {pgmax }}$ (Liu et al., 2014; Zhu et al., 2017).

Lu et al. (2019) recently developed an equation to estimate the concentration of gaseous sulfuric acid in Beijing. The equation is expressed as follows:

$\left[\mathrm{H}_{2} \mathrm{SO}_{4}\right]=280.05 \times \mathrm{UVB}^{0.14} \times\left[\mathrm{SO}_{2}\right]^{0.40}$.

The units for $\left[\mathrm{H}_{2} \mathrm{SO}_{4}\right]$ and $\left[\mathrm{SO}_{2}\right]$ are molec. $\mathrm{cm}^{-3}$, and the unit for UVB (ultraviolet $\mathrm{B}$ ) is $\mathrm{Wm}^{-2}$. The re- ported error was within $20 \%$ for the calculated concentrations against the observations in Beijing ( $\mathrm{Lu}$ et al., 2019). UVB occupies $5 \%$ of the ultraviolet radiation that reaches Earth's surface (https://en.wikipedia.org/wiki/ Ultraviolet\#cite_note-Skin_Cancer_Foundation-23, last access: 23 December 2020). Thus, UVB values were obtained by multiplying the downward ultraviolet radiation at the surface by $5 \%$ in this study, and the ultraviolet radiation data were downloaded from the Climate Data Store (https://cds.climate.copernicus.eu/, last access: 23 December 2020). The contribution of sulfuric acid vapor to particle growth was calculated based on the method reported by Kulmala et al. (2001) and Nieminen et al. (2010).

$R=\left(\left[\mathrm{H}_{2} \mathrm{SO}_{4}\right]_{\mathrm{avg}} / C\right) \times 100 \%$,

where $\left[\mathrm{H}_{2} \mathrm{SO}_{4}\right]_{\text {avg }}$ is the average concentration of $\mathrm{H}_{2} \mathrm{SO}_{4}$ vapor during the particle growth period and $C$ is the total concentration of condensable vapor for the particle growth. Here, the surface vapor pressure of the condensable material is assumed to be zero, and $C$ can be calculated based on the equation of Kulmala et al. (2001).

$$
\begin{aligned}
C & =\rho \frac{D_{\mathrm{pg} 2}^{2}-D_{\mathrm{pg} 1}^{2}}{2}+\left[\frac{4}{3 \mathrm{a}}-0.623\right] \lambda\left(D_{\mathrm{pg} 2}-D_{\mathrm{pg} 1}\right) \\
& +0.623 \lambda^{2} \ln \frac{\lambda+D_{\mathrm{pg} 2}}{\lambda+D_{\mathrm{pg} 1}} / \Delta t D m,
\end{aligned}
$$

where $\rho$ is the particle density in $\mathrm{g} \mathrm{cm}^{-3}, a$ is the mass accommodation coefficient (i.e., sticking probability), $\lambda$ is the mean free path in $\mathrm{nm}, \Delta t$ (s) is the time during particle growth from $D_{\mathrm{pg} 1}$ to $D_{\mathrm{pg} 2}, D\left(\mathrm{~cm}^{2} \mathrm{~s}^{-1}\right)$ is the diffusion coefficient of the condensing vapor, and $m$ is the molecular mass of the condensable vapor in $\mathrm{g} \mathrm{mol}^{-1}$.

To calculate the survival probability (SP) of grown new particles beyond 50 or $70 \mathrm{~nm}$, temporal variations in $N_{50-200 \mathrm{~nm}}$ and $N_{70-200 \mathrm{~nm}}$ were plotted; e.g., Fig. S2a-b showed the temporal results on 25 August 2014. With an increase of the height of the planetary boundary layer (PBL, Fig. S2d), the stable minimum $N_{50-200 \mathrm{~nm}}$ or $N_{70-200 \mathrm{~nm}}$ can be clearly identified approximately $2-3 \mathrm{~h}$ after the NPF event to be observed. The minimum $N_{50-200 \mathrm{~nm}}\left(N_{70-200 \mathrm{~nm}}\right)$ remained constant for approximately $2 \mathrm{~h}(4 \mathrm{~h})$, even though the height of the PBL increased continuously. The new particle signal likely mixed well within the whole PBL. The stable maximum $N_{50-200 \mathrm{~nm}}$ or $N_{70-200 \mathrm{~nm}}$ can be also clearly identified approximately $11-13 \mathrm{~h}$ later, when the height of the PBL has been lowered down a lot from the maximum. The change in height of the PBL had no detectable influence on the maximum $N_{50-200 \mathrm{~nm}}$ or $N_{70-200 \mathrm{~nm}}$ because the growth of $>30 \mathrm{~nm}$ new particles to a larger size probably occurred within the PBL. The difference between the two values was thereby used to estimate the net maximum number concentration of grown new particles beyond 50 or $70 \mathrm{~nm}$, i.e., $N_{50-200 \mathrm{~nm}}$ (net) and $N_{70-200 \mathrm{~nm}}$ (net). Thus, $\mathrm{SP}_{50 \mathrm{~nm}}$ and 
$\mathrm{SP}_{70 \mathrm{~nm}}$ were estimated as

$\mathrm{SP}_{50 \mathrm{~nm}}=\frac{N_{50-200 \mathrm{~nm}}(\text { net })}{\mathrm{NMINP}} \times 100 \%$,

$\mathrm{SP}_{70 \mathrm{~nm}}=\frac{N_{70-200 \mathrm{~nm}}(\text { net })}{\mathrm{NMINP}} \times 100 \%$.

Note that the observed number concentrations of newly grown particles with a larger size sometimes exceeded those with a smaller size under the condition of spatial heterogeneity of NPF. In these cases, that is, for NPF events occurring on 23 June and 12 and 15 August, SP was not calculated.

Following Eq. (1) proposed by Kulmala et al. (2001), in which $D_{\mathrm{pg} 1}$ and $D_{\mathrm{pg} 2}$ are used to calculate $C$, the amount of chemical species required to grow new particles from $D_{\mathrm{pg} 1}$

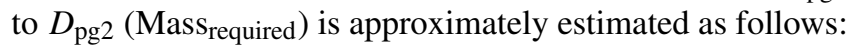

Mass $_{\text {required }}=4 / 3 \pi\left[\left(D_{\mathrm{pg} 2} / 2\right)^{3}-\left(D_{\mathrm{pg} 1} / 2\right)^{3}\right] \times N \times \rho$,

where $\rho$ is the density, which is assumed to be $1.5 \mu \mathrm{g} \mathrm{m}^{-3}$ for OOA (or SOA) and $1.7 \mu \mathrm{g} \mathrm{m}^{-3}$ for $\mathrm{NH}_{4} \mathrm{NO}_{3}$, respectively. Considering that the particle number concentration may decrease because of the dry deposition, diffusion and dilution effects, and particle coagulation, $N$ represents the integral value of new particle number concentrations with the geometric median diameter of new particles from $D_{\mathrm{pg} 2}-3 \sigma$ to $D_{\mathrm{pg} 2}+3 \sigma$. The approximate value may overestimate the required amount because particle-particle coagulation has not been deducted.

\subsection{Model description}

The US EPA (Environmental Protection Agency) Community Multiscale Air Quality Modeling Systems (CMAQ version 5.0.2; Byun and Schere, 2006) was applied to simulate inorganic ions such as $\mathrm{NO}_{3}^{-}, \mathrm{SO}_{4}^{2-}, \mathrm{NH}_{4}^{+}$, and $\mathrm{SOA}$ in $\mathrm{PM}_{2.5}$ over East Asia. Figure $\mathrm{S} 1$ shows the nested domains, with the $36 \mathrm{~km}$ domain 1 (d01) and the $12 \mathrm{~km}$ domain 2 (d02) over eastern China and adjacent seas. The vertical resolution includes 14 logarithmic structure layers from the surface to the tropopause, with the first model layer height of $36 \mathrm{~m}$ a.g.l. Meteorological fields were generated by the Weather Research and Forecasting (WRF) model (v3.7). The initial and boundary conditions were obtained from the National Center for Environmental Prediction (NCEP) FNL (Final) Operational Global Analysis datasets (http://rda.ucar.edu/datasets/ds083.2, last access: 23 December 2020). The major physics options included the Lin microphysics scheme, RRTM (Rapid Radiative Transfer Model) longwave radiation scheme, Goddard shortwave scheme, Monin-Obukhov surface-layer scheme, thermal diffusion land-surface scheme, and YSU (Yonsei University) land-surface scheme. The WRF hourly output files were processed using the Meteorology-Chemistry Interface Processor (MCIP v4.3). In CMAQ, the CB05tucl chemical mechanism module coupled with AERO6 was used to simulate (a) Dec 2011

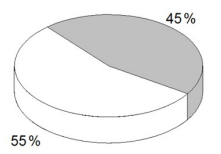

(d) Jul 2014
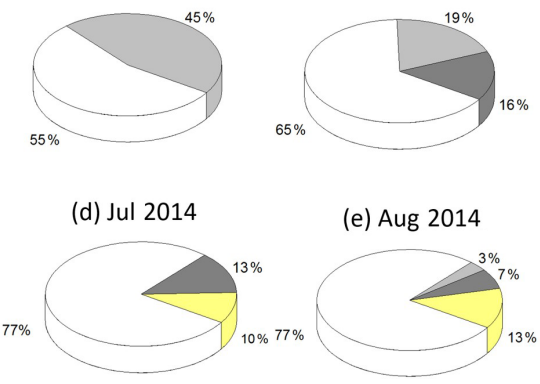

(e) Aug 2014
Figure 2. Occurrence frequencies of difference growth patterns of NPF events in observational months.

the concentrations of gases and aerosols. Initial conditions (ICONs) and boundary conditions (BCONs) of pollutants in d01 were generated using the results from a global chemistry model of GEOS-Chem (Goddard Earth Observing System), while ICONs and BCONs for d02 were obtained from the results of d01. The Multi-resolution Emission Inventory for China (MEIC) in 2014, developed by Tsinghua University (http://www.meicmodel.org/, last access: 23 December 2020), combined with BVOC (biogenic volatile organic compound) emissions generated from the Model of Emissions of Gases and Aerosols from Nature (MEGAN v2.0.4, Guenther et al., 2006), was used in this study. A spin-up time of $5 \mathrm{~d}$ was used to minimize the influence of ICONs.

Liu et al. (2010a, b), Qi et al. (2018), and Zhang et al. (2019) reported the validation of the CMAQ application in China, in which good agreements between the simulated and measured concentrations of particulate components were generally obtained. During the study period, the model results of $\mathrm{SO}_{4}^{2-}, \mathrm{NH}_{4}^{+}$, and $\mathrm{NO}_{3}^{-}$met the benchmark criteria of the above three species (US EPA, 2007), with correlations between modeled and measured values larger than 0.61 (Table S1). The modeled concentrations of $\mathrm{NH}_{4}^{+}$reasonably agree with the observations with a normalized mean bias (NMB) of $6 \%$. The NMB slightly increased up to $12 \%$ for the modeled concentrations of $\mathrm{SO}_{4}^{2-}$. The modeled values of $\mathrm{NO}_{3}^{-}$were underestimated with NMBs of $-29 \%$. The modeled values of SOA were largely underestimated, although the correlation between modeled and measured values was 0.53 . Underestimation of SOA is a common weakness of the model simulation because a fraction of SOA precursors is not included, and some key formation pathways of SOA may still be missing in current air quality models (Baek et al., 2011; Knote et al., 2014). The modeled values of SOA can thus be considered as semiquantitative evidence to facilitate analysis. Detailed evaluation results of this study are provided in the Supplement. 
Table 1. Characteristics of NPF events in Beijing.

\begin{tabular}{|c|c|c|c|c|c|c|c|c|}
\hline Season & Date & Period & $\begin{array}{l}\text { GR or SR } \\
\left(\mathrm{nm} \mathrm{h}^{-1}\right)\end{array}$ & $\begin{array}{r}\text { NMINP } \\
\left(10^{4} \mathrm{~cm}^{-3}\right)\end{array}$ & $\begin{array}{r}D_{\text {pgmax }} \\
(\mathrm{nm})\end{array}$ & $\begin{array}{r}\mathrm{SO}_{2} \\
(\mathrm{ppb})^{\mathrm{e}}\end{array}$ & $\begin{array}{l}\text { SP } \\
(\%)\end{array}$ & $\begin{array}{r}\mathrm{O}_{3}+\mathrm{NO}_{2} \\
(\mathrm{ppb})^{\mathrm{h}}\end{array}$ \\
\hline \multirow[t]{10}{*}{ Winter } & 10 December $2011^{\mathrm{a}}$ & 09:00-15:00 & - & 1.5 & 11 & $2.5-4.4$ & - & $36-38$ \\
\hline & 11 December $2011^{\mathrm{a}}$ & $11: 00-14: 00$ & - & 2.5 & 11 & $7.2-16$ & - & $34-40$ \\
\hline & 14 December $2011^{\mathrm{a}}$ & 10:00-16:00 & - & 1.1 & 11 & $3.1-5.8$ & - & $31-39$ \\
\hline & 15 December $2011^{\mathrm{a}}$ & $10: 30-17: 30$ & - & 1.0 & 11 & $1.6-5.3$ & - & $33-39$ \\
\hline & 21 December 2011 & 13:00-18:00 & - & 0.5 & 10 & $1.4-3.5$ & - & $33-43$ \\
\hline & 21 December $2011^{\mathrm{a}}$ & 09:00-12:00 & - & 1.1 & 12 & $2.5-5.9$ & - & $22-61$ \\
\hline & 22 December 2011 & $10: 00-15: 00$ & - & 1.3 & 10 & $2.3-6.0$ & - & $32-41$ \\
\hline & 22 December $2011^{\mathrm{a}}$ & $11: 30-15: 40$ & - & 2.3 & 10 & $2.3-7.6$ & - & $23-41$ \\
\hline & 23 December 2011 & 11:00-14:00 & - & 0.7 & 10 & $3.5-16$ & - & $32-43$ \\
\hline & 23 December $2011^{a}$ & $09: 40-16: 30$ & - & 0.7 & 10 & $3.6-9.2$ & - & $38-41$ \\
\hline \multirow[t]{9}{*}{ Spring } & 12 April 2012 & $09: 20-18: 20$ & 2.2 & 2.9 & 27 & $1.0-2.3$ & - & $41-57$ \\
\hline & 13 April 2012 & 11:20-19:00 & 6.2 & 1.5 & 25 & $1.4-3.6$ & - & $61-76$ \\
\hline & 14 April 2012 & 12:00-19:00 & 9.3 & 0.8 & 31 & $2.0-7.7$ & - & $73-88$ \\
\hline & 15 April 2012 & 11:30-19:00 & - & 1.7 & 12 & $0.0-2.1$ & - & $57-66$ \\
\hline & 16 April 2012 & $10: 22-14: 20$ & 7.9 & 1.2 & 38 & $1.3-3.7$ & - & $52-69$ \\
\hline & 25 April 2012 & 10:07-20:00 & - & 1.0 & 11 & $0.0-1.9$ & - & $47-54$ \\
\hline & 25 April $2012^{\mathrm{a}}$ & 10:07-20:00 & - & 1.1 & 11 & $0.0-1.9$ & - & $47-54$ \\
\hline & 27 April 2012 & 09:40-16:00 & - & 2.1 & 15 & - & - & - \\
\hline & 27 April $2012^{\mathrm{a}}$ & 09:40-16:00 & - & 1.4 & 15 & - & - & - \\
\hline \multirow[t]{27}{*}{ Summer } & 1 June 2014 & $12: 00-16: 00$ & - & 1.1 & 15 & $0.4-1.5$ & - & $77-88$ \\
\hline & 3 June 2014 & 08:00-12:00 & 4.3 & 3.0 & 20 & $1.2-10$ & - & $56-78$ \\
\hline & 4 June 2014 & $11: 30-22: 00$ & 11 & 1.2 & 27 & $1.2-3.7$ & - & $67-118$ \\
\hline & 7 June 2014 & 09:00-(+1) 03:00 & 5.5 & 1.3 & 48 & $0.0-1.3$ & - & $32-64$ \\
\hline & 8 June 2014 & 09:00-14:00 & 12 & 1.5 & 50 & $3.5-9.0$ & - & $41-110$ \\
\hline & 9 June 2014 & $10: 55-19: 40$ & 7.1 & 1.1 & 40 & $1.0-4.5$ & - & $55-122$ \\
\hline & 11 June 2014 & 09:20-(+1) 03:20 & $5.4 / 5.1^{\mathrm{b}} / 9.0^{\mathrm{c}}$ & 1.1 & $36 / 84^{\mathrm{d}}$ & $0.0-1.2$ & $54 / 36^{f}$ & $43-89$ \\
\hline & 12 June 2014 & $08: 00-15: 00$ & 3.6 & 3.1 & 25 & $1.2-7.3$ & - & $50-87$ \\
\hline & 18 June 2014 & $09: 20-20: 20$ & 14 & 1.8 & 88 & $0.4-2.8$ & $56 / 39^{f}$ & $56-136$ \\
\hline & 23 June 2014 & $11: 20-(+1) 01: 22$ & $10 / 8.0^{\mathrm{b}} / 10^{\mathrm{c}}$ & 0.5 & $79 / 90^{\mathrm{d}}$ & $0.2-1.3$ & $\mathrm{~N} / \mathrm{A}^{\mathrm{g}}$ & $53-135$ \\
\hline & 27 June 2014 & 09:00-(+1) 03:00 & $5.2 / 9.7^{\mathrm{c}}$ & 1.5 & $35 / 75^{\mathrm{d}}$ & $0.1-1.9$ & $60 / 39^{f}$ & 44-99 \\
\hline & 28 June 2014 & 07:00-19:00 & 3.0 & 1.8 & 39 & $0.6-10$ & - & $15-106$ \\
\hline & 29 June 2014 & $08: 50-15: 00$ & 7.3 & 0.7 & 40 & $1.7-9.2$ & - & $62-144$ \\
\hline & 8 July 2014 & 09:30-21:00 & 16 & 1.0 & 45 & $0.9-4.3$ & - & $52-79$ \\
\hline & 9 July 2014 & 10:00-17:30 & 15 & 2.4 & 32 & $0.9-4.3$ & - & $42-91$ \\
\hline & 12 July 2014 & 09:00-(+1) 04:00 & 6.0 & 1.6 & 80 & $1.8-3.5$ & $46 / 27^{\mathrm{f}}$ & $36-84$ \\
\hline & 13 July 2014 & $07: 30-(+1) 04: 00$ & 6.0 & 2.5 & 100 & $2.1-5.6$ & $39 / 22^{\mathrm{f}}$ & $37-78$ \\
\hline & 14 July 2014 & 08:00-20:00 & 17 & 2.5 & 50 & $3.2-5.3$ & - & $41-135$ \\
\hline & 25 July 2014 & $11: 20-22: 00$ & 9.0 & 0.6 & 39 & $3.9-6.0$ & - & $86-109$ \\
\hline & 26 July 2014 & $14: 33-(+1) 08: 00$ & $12 / 8.2^{\mathrm{b}} / 7.5^{\mathrm{c}}$ & 0.9 & $57 / 120^{\mathrm{d}}$ & $5.3-11$ & $46 / 23^{f}$ & $23-130$ \\
\hline & 6 August 2014 & $08: 41-(+1) 08: 00$ & $4.8 / 10^{\mathrm{c}}$ & 1.4 & $23 / 115^{\mathrm{d}}$ & $1.4-4.6$ & $54 / 44^{\mathrm{f}}$ & $25-82$ \\
\hline & 12 August 2014 & $10: 00-22: 00$ & $7.3 / 6.5^{\mathrm{c}}$ & 1.3 & $50 / 75^{\mathrm{d}}$ & $2.1-4.6$ & $\mathrm{~N} / \mathrm{A}^{\mathrm{g}}$ & $47-109$ \\
\hline & 15 August 2014 & $10: 10-(+1) 03: 42$ & $8.3 / 8.7^{\mathrm{c}}$ & 0.9 & $69 / 110^{\mathrm{d}}$ & $2.1-6.3$ & N/A ${ }^{g}$ & $41-119$ \\
\hline & 24 August 2014 & 08:00-19:00 & 3.3 & 3.0 & 38 & $3.9-8.1$ & - & $30-52$ \\
\hline & 25 August 2014 & 07:50-(+1) 09:00 & 5.1 & 2.4 & 80 & $2.1-8.4$ & $35 / 20^{f}$ & $32-75$ \\
\hline & 26 August 2014 & 09:00-23:00 & 5.1 & 1.1 & 30 & $0.7-7.0$ & - & 44-95 \\
\hline & 27 August 2014 & $12: 25-14: 30$ & - & 1.1 & 12 & - & - & - \\
\hline
\end{tabular}

${ }^{a}$ The NPF events occurred on the street site. ${ }^{b}$ Refers to the shrinkage rates of the two-stage growth-B pattern. ${ }^{c}$ Refers to the second-stage growth rates. ${ }^{\mathrm{d}}$ Refers to the $D_{\text {pgmax }}$ of the second-stage growth. ${ }^{\text {e }}$ Refers to the mixing ratio range of $\mathrm{SO}_{2}$ during the NPF period. ${ }^{\text {f }}$ Refers to the SP with the $D_{\text {pg }}$ increasing up to 50 and $70 \mathrm{~nm}$, respectively. ${ }^{\mathrm{g}}$ Refers to Eq. (5) not being applicable for calculating SP during the NPF events. ${ }^{\text {h }}$ Refers to the mixing ratio range of $\mathrm{O}_{x}\left(\mathrm{NO}_{2}+\mathrm{O}_{3}\right)$ during the NPF period. 


\section{Results}

\subsection{Overview of NPF events in three campaigns}

A total of $46 \mathrm{NPF}$ events were observed during the three campaigns in Beijing, and the occurrence frequencies of NPF events decreased clearly in the rainy season (Table 1 and Fig. 2). In campaign 1, seven NPF events were observed during 10-23 December 2011 (7 out of 14) at the street site. During 16-23 December, three NPF events were observed (three out of eight) at the rooftop site, which occurred simultaneously with the events at the street site. In campaign 2, seven NPF events were observed at the rooftop site during 12-27 April 2012 (7 out of 16). During 18-27 April 2012, two NPF events were observed at the street site simultaneously with the events observed ( 2 out of 10) at the rooftop site. In campaign 3, $13 \mathrm{NPF}$ events occurred in June out of a total of 30 observational days. The occurrence frequency decreased to approximately $20 \%$ in July and August (7 NPF events from 31 observational days). Beijing enters the rainy season in July and August, and the weather conditions are unfavorable for NPF events (Wu et al., 2007).

The NMINP varied largely from event to event in the 5 months, but the monthly averages were generally closer to each other. For example, the monthly average values were $1.5 \pm 0.8 \times 10^{4} \mathrm{~cm}^{-3}$ (average value \pm standard deviation) in June 2014 and $1.6 \pm 0.8 \times 10^{4} \mathrm{~cm}^{-3}$ in July and August 2014. The large values of NMINP implied the NPF to be an important source of ambient particles when particle number concentrations were considered. The NMINP was $1.6 \pm 0.7 \times 10^{4} \mathrm{~cm}^{-3}$ at the rooftop site in April 2012, but it was lower $\left(1.3 \pm 0.2 \times 10^{4} \mathrm{~cm}^{-3}\right)$ at the street site. In December 2011, the NMINP was only $8.3 \pm 4.2 \times 10^{3} \mathrm{~cm}^{-3}$ at the rooftop site, but it was still $1.5 \pm 0.7 \times 10^{4} \mathrm{~cm}^{-3}$ at the street site. There was no significant difference in the NMINP at the rooftop site between April and June-August, but the values in the 4 months were significantly larger than those at the rooftop site in December $(p<0.05)$. Zhu et al. (2017) discussed the seasonal difference in the NMINP between the two nearby sites in terms of the effects of the condensation sink and low temperature.

\subsection{Season-dependent growth patterns of newly formed particles}

As reported by Dusek et al. (2006), atmospheric particles with a diameter below $60 \mathrm{~nm}$ were unlikely to be activated as $\mathrm{CCN}$ at a normal SS, such as $\leq 0.2 \%$. Investigating the growth behaviors of newly formed particles, three growth patterns, classes I, II, and III, were identified on the basis of their potentials to act as CCN at normal SS (Figs. 3-5 and S3-S6). Class I was characterized by no apparent particle growth. For example, the fitted $D_{\text {pg }}$ of new particles was almost constant at $11 \mathrm{~nm}$ for $\sim 10 \mathrm{~h}$ on 25 April 2012, until the new particle signal dropped to a negligible level (Table 1 and Fig. S3a). The new particles unlikely grew to CCN size prior to removal from ambient air.

Class II was characterized by the fitted $D_{\mathrm{pg}}$ of new particles growing from $10 \pm 2$ to $20-50 \mathrm{~nm}$, as shown in Fig. S3c; e.g., class II can be further subclassified into four scenarios. In scenario 1, the new particle growth lasted for a few hours with $D_{\text {pg }}$ increasing to $27-48 \mathrm{~nm}$, after which it stopped (Fig. S3c). The increased size was maintained for a few hours until the new particle signal dropped to a negligible level. The growth of newly formed particles seemingly encountered a ceiling in scenario 1, in which new particles grown at the maximum $D_{\mathrm{pg}}$ unlikely contributed to $\mathrm{CCN}$ at normal SS. The ceiling prevented newly formed particles from growing to $\mathrm{CCN}$ size in scenario 1 . The possibility of new particles to grow to $\mathrm{CCN}$ size in scenarios 2-4 remains unknown. For example, new particles grew with $D_{\text {pg }}$ approaching $32-45 \mathrm{~nm}$ in scenario 2. Afterwards, the signal of the new particles was apparently replaced by another signal of the new particles with an obviously smaller diameter (Fig. S3e). In scenario 3 , new particles grew with $D_{\text {pg }}$ increasing to $20-50 \mathrm{~nm}$, and the new particle signal was overwhelmed by aged plumes. In the $0.5 \mathrm{~h}$ or $1 \mathrm{~h}$ switching from new particle signals to aged plume signals, $D_{\text {pg }}$ rapidly increased by dozens of nanometers (Fig. S3g), similar to those reported by Man et al. (2015). Scenario 3 was quite common in the presence of air pollutant plumes (Levy et al., 2013; Zhang et al., 2015). In scenario 4, the $D_{\text {pg }}$ of new particles increased to $31-50 \mathrm{~nm}$. Afterwards, no data were available to judge any further particle growth (Fig. S3i).

In class III, the $D_{\mathrm{pg}}$ of new particles experienced either a continuous increase or a noncontinuous increase with the final $D_{\text {pgmax }}$ closer to $75-120 \mathrm{~nm}$ (Figs. 3-5 and S4-S6). Class III can be further classified into three growth patterns, which will be detailed in later sections. In addition to particle size, various factors such as chemical composition, particle mixing states, and meteorological conditions may also largely affect CCN activation of aerosols with $D_{\text {pg }}$ beyond $70 \mathrm{~nm}$ (Ma et al., 2016; Rose et al., 2017; Lee et al., 2019). Although new particles in class III can grow to CCN size, the CCN activation of grown new particles has been reported to vary case by case (Wiedensohler et al., 2009; Yue et al., 2011; Li et al., 2015; Ma et al., 2016). Overall, the $D_{\text {pgmax }}$ of grown new particles increased from class I to class III.

In December, all of these observed NPF events (three NPF events at the rooftop site plus seven NPF events at the street site) were subject to class I (Table 1 and Fig. 2a). In April, three out of seven NPF events at the rooftop site and three NPF events simultaneously observed at the street site were subject to class I. The remaining four NPF events at the rooftop site in April were subject to class II, of which half belonged to scenarios 3 and 4 (Table 1 and Fig. 2b). In JuneAugust, a total of 2, 14, and 11 out of 27 NPF events were subject to class I, class II, and class III (Table 1 and Fig. 2ce), respectively. Newly formed particles in the summer appeared to have a high probability of growing to $\mathrm{CCN}$ size, 

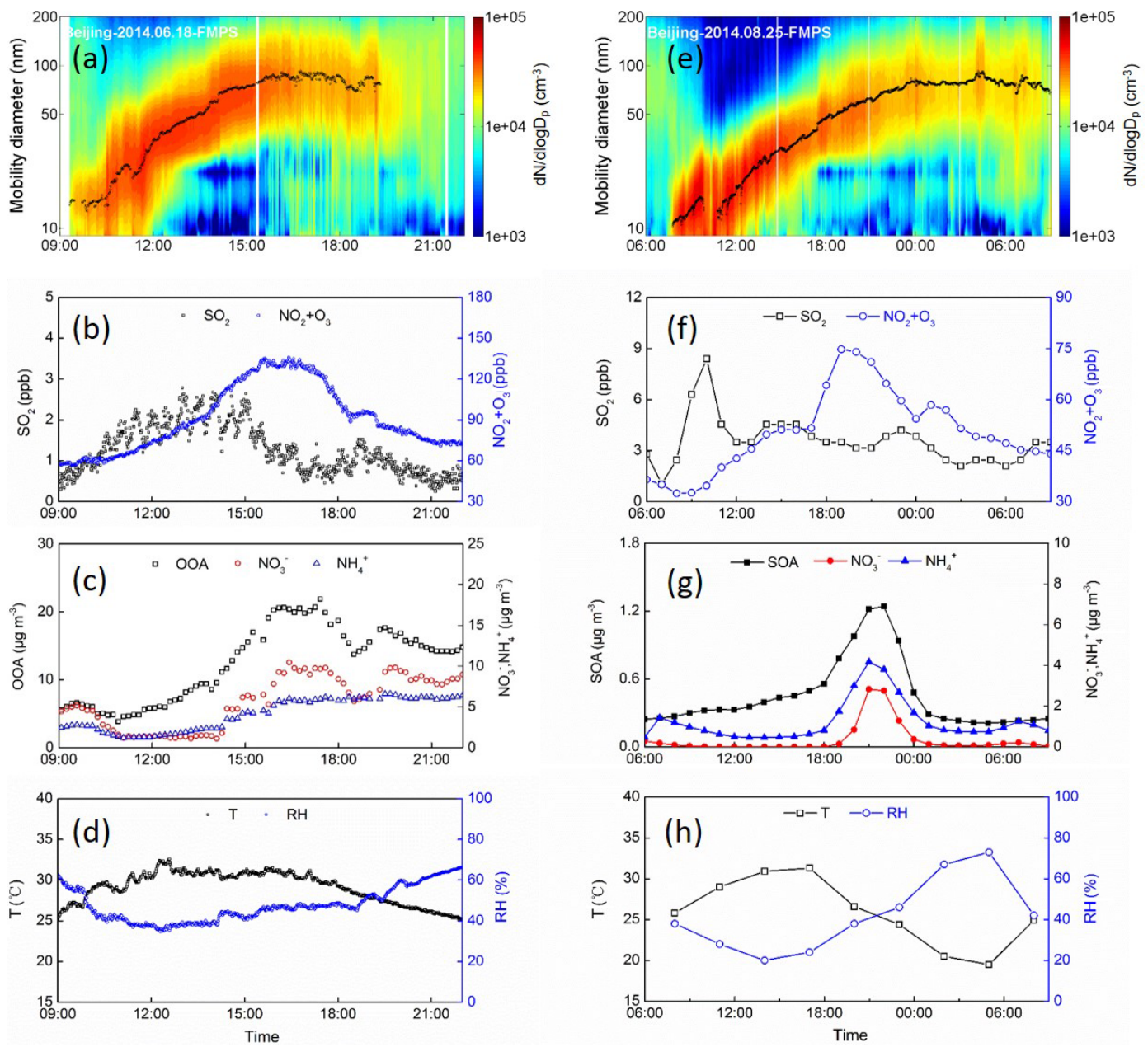

Figure 3. NPF events on 18 June and 25 August 2014. (a, e) Contour plot of particle number concentration. (b, f) Time series of observed mixing ratios of $\mathrm{SO}_{2}$ and $\mathrm{NO}_{2}+\mathrm{O}_{3}$. (c) Time series of observed OOA, $\mathrm{NO}_{3}^{-}$, and $\mathrm{NH}_{4}^{+}$in $\mathrm{PM}_{1.0}$. (d, h) Time series of ambient $T$ (temperature) and $\mathrm{RH}$ (relative humidity). (g) Time series of modeled $\mathrm{SOA}, \mathrm{NO}_{3}^{-}$, and $\mathrm{NH}_{4}^{+}$in $\mathrm{PM}_{2.5}$. Please note that the date format used in this figure is year month day (yyyy.mm.dd).

at least in 11 out of 27 NPF events. On the other hand, newly formed particles in the winter were unlikely to act as a potential source of $\mathrm{CCN}$ because their $D_{\text {pgmax }}$ reached only $11 \pm 1 \mathrm{~nm}$. The occurrence probability of class I events largely decreased in April and summer, with three class I NPF events in April, no class I NPF event in July, and one class I NPF event each in June and August (Table 1 and Fig. 2c-e). Additionally, the lack of class III NPF events in April implied that newly formed particles were less likely to grow to CCN size at normal SS.

Overall, the growth patterns of newly formed particles are strongly season-dependent, with a generally larger $D_{\text {pgmax }}$ in June-August. The mechanisms for the growth of newly formed particles to CCN size in class III are thus critical for understanding the importance of grown new particles acting as a potential source of $\mathrm{CCN}$ at normal SS. The new particle growth behaviors in class III NPF events were thus analyzed in further detail, and SPs of grown particles with $D_{\text {pgmax }}$ at 50 and $70 \mathrm{~nm}$ were also estimated.

\subsection{Growth patterns of newly formed particles reaching $\mathrm{CCN}$ size}

Analyzing the observational results for June, July, and August 2014 separately, the occurrence frequencies of class III NPF events in the 3 months were found to be very close to each other, with four, three, and four in June, July, and August, respectively. The 11 NPF events can be further classified into three particle growth patterns: one-stage particle growth pattern, two-stage particle growth-A pattern, and two-stage particle growth-B pattern.

The one-stage particle growth pattern occurred in 4 out of $11 \mathrm{NPF}$ events, in which the fitted $D_{\text {pg }}$ of newly formed particles continuously increased from 11 to $80-100 \mathrm{~nm}$ in 6$17 \mathrm{~h}$ on 18 June, 12-13 July, and 25 August 2014 (Figs. 3 and 

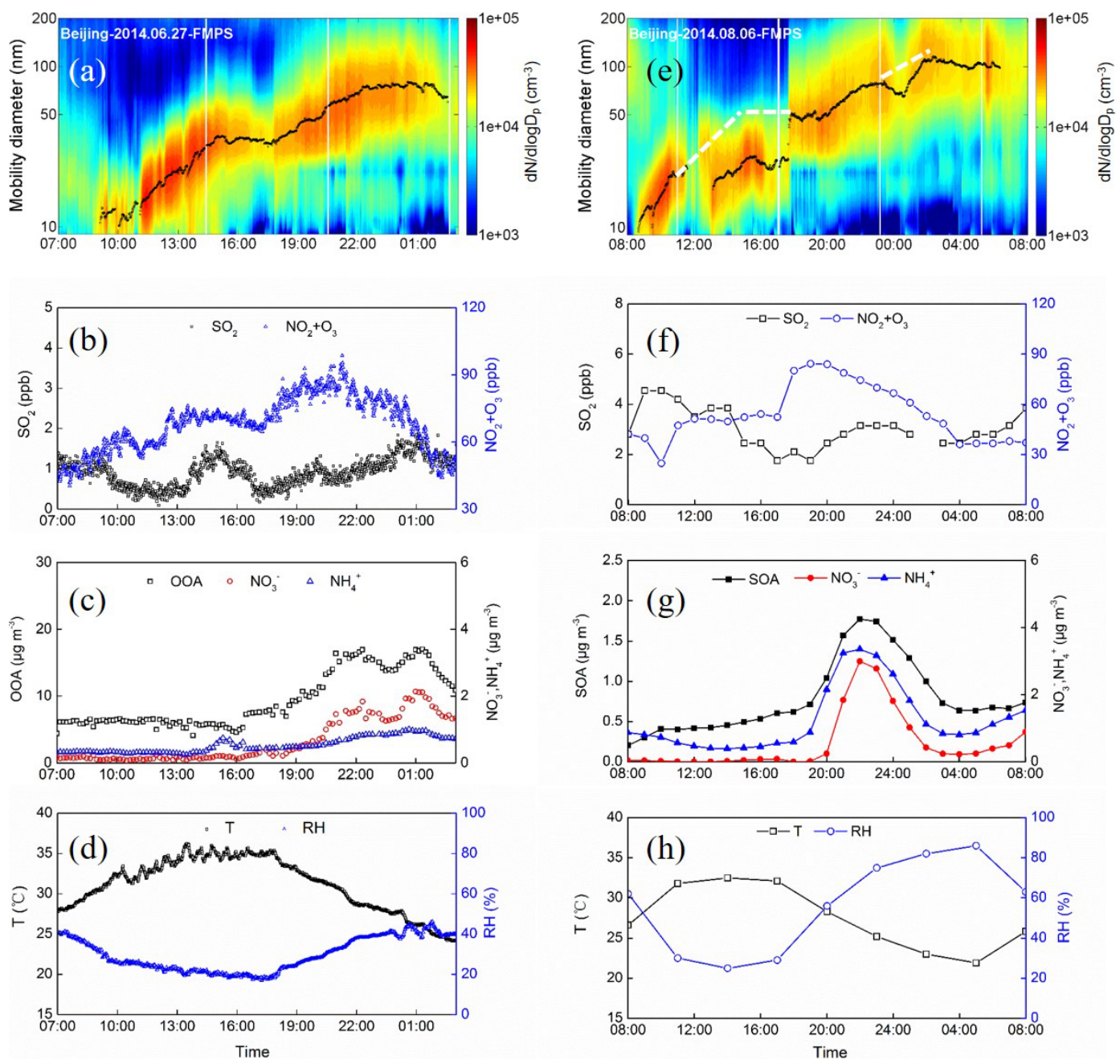

Figure 4. NPF events on 27 June and 6 August 2014. (a, e) Contour plot of particle number concentration. (b, f) Time series of observed mixing ratios of $\mathrm{SO}_{2}$ and $\mathrm{NO}_{2}+\mathrm{O}_{3}$. (c) Time series of observed OOA, $\mathrm{NO}_{3}^{-}$, and $\mathrm{NH}_{4}^{+}$in $\mathrm{PM}_{1.0}$. (d, h) Time series of ambient $T$ and RH. (g) Time series of modeled $\mathrm{SOA}, \mathrm{NO}_{3}^{-}$, and $\mathrm{NH}_{4}^{+}$in $\mathrm{PM}_{2.5}$. Please note that the date format used in this figure is year month day (yyyy.mm.dd).

S4). The growth of new particles stopped at $\sim 24: 00$ in three out of four NPF events, while it stopped as early as $\sim 16: 00$ in the last event.

Of the 11 NPF events, four events exhibited the two-stage particle growth-A pattern. The initial $D_{\mathrm{pg}}$ of newly formed particles varied from 9 to $22 \mathrm{~nm}$ in different events, in which the particles grew to a larger size in the daytime, then oscillated for several hours, and eventually restarted the increase at night (Figs. 4 and S5). In two out of four events, the increase in the $D_{\text {pg }}$ of newly formed particles stopped for $2-3 \mathrm{~h}$ in the middle period and then resumed to reach up to $75 \mathrm{~nm}$ at 22:00. In the other two out of four events, $D_{\text {pg }}$ remained unchanged for $\sim 4 \mathrm{~h}$ in the middle period and then increased, reaching up to $110-115 \mathrm{~nm}$ at 01:00 the next day.

A total of 3 out of 11 NPF events exhibited the twostage particle growth-B pattern, in which the $D_{\mathrm{pg}}$ of newly formed particles increased from 10-19 to $36-79 \mathrm{~nm}$, then decreased to $24-50 \mathrm{~nm}$ in the next $2-4 \mathrm{~h}$, and $D_{\mathrm{pg}}$ increased again, reaching up to $84-120 \mathrm{~nm}$ (Figs. 5 and S6). In two events, the decrease in newly formed particles occurred at approximately 18:00, for example, $D_{\mathrm{pg}}$ from 78 to $52 \mathrm{~nm}$ at 18:00-21:22 on 23 June and $D_{\text {pg }}$ from 57 to $35 \mathrm{~nm}$ at 17:50 20:30 on 26 July. However, the shrinkage occurred as early as $15: 20-17: 20$ on 11 June with $D_{\mathrm{pg}}$ from 38 to $24 \mathrm{~nm}$.

\section{Discussion}

\subsection{One-stage new particle growth to $\mathrm{CCN}$ size}

Among the four one-stage growth NPF events, newly formed particles took the shortest time to reach the maximum size on 18 June 2014 (Fig. 3a). The NPF event was first observed 

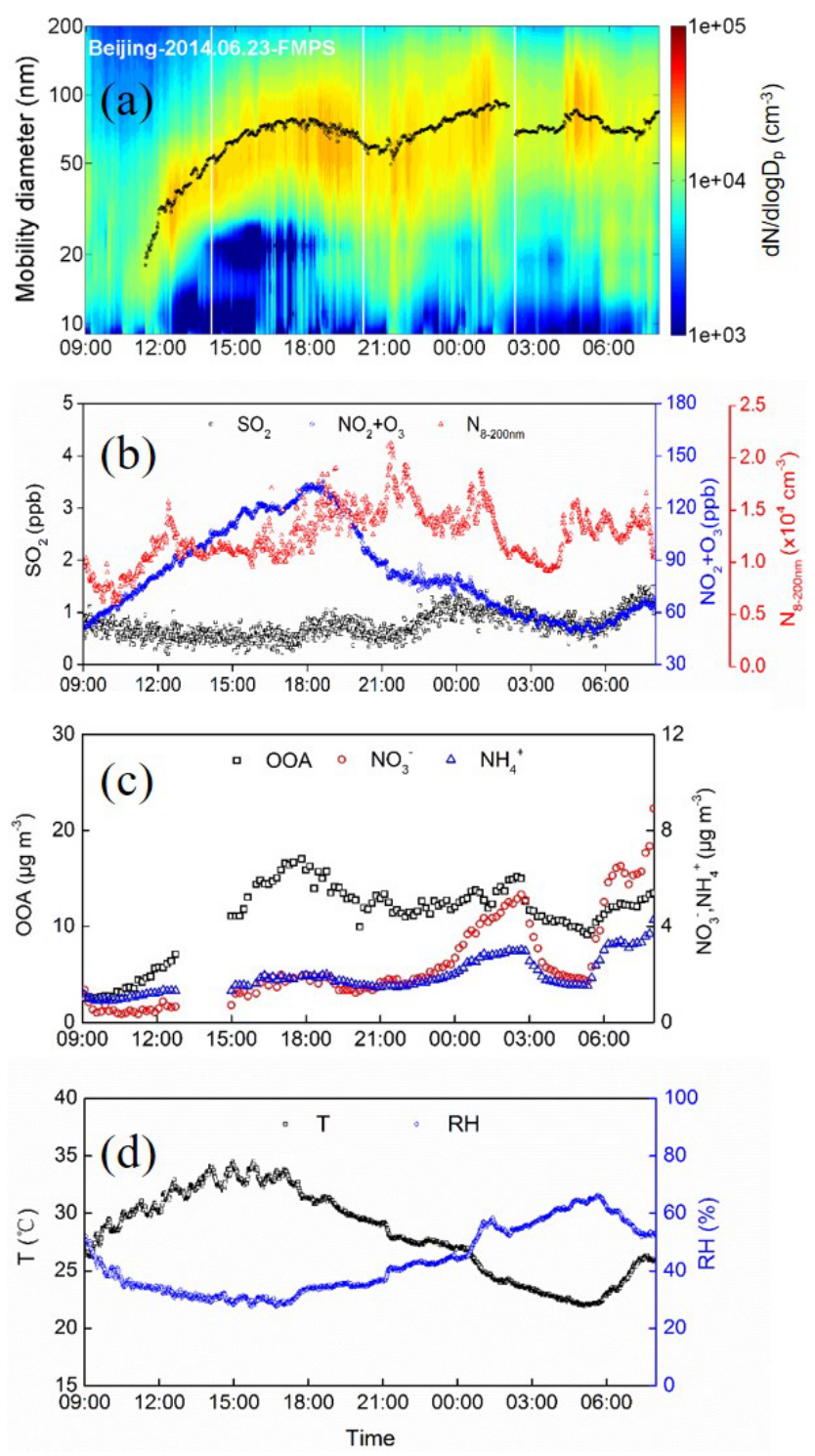

Figure 5. NPF event on 23 June 2014. (a) Contour plot of particle number concentration. (b) Time series of observed mixing ratios of $\mathrm{SO}_{2}, \mathrm{NO}_{2}+\mathrm{O}_{3}$, and $N_{8}-200 \mathrm{~nm}$. (c) Time series of observed OOA, $\mathrm{NO}_{3}^{-}$, and $\mathrm{NH}_{4}^{+}$in $\mathrm{PM}_{1.0}$. (d) Time series of ambient $T$ and $\mathrm{RH}$. Please note that the date format used in this figure is year month day (yyyy.mm.dd).

at 09:20, lasting for $11 \mathrm{~h}$. From 09:20 to 10:36, no apparent growth in newly formed particles was observed. The concentrations of gaseous precursors during that period may have been too low to cause a detectable growth in new particles with diameters $>10 \mathrm{~nm}$, similar to the observations reported in Hong Kong SAR by Man et al. (2015). After 10:36, the $D_{\text {pg }}$ of newly formed particles increased from 14 to $88 \mathrm{~nm}$ at 15:54 with a particle growth rate of $14 \mathrm{~nm} \mathrm{~h}^{-1}$. The ambient relative humidity $(\mathrm{RH})$ was approximately $40 \%$ with an ambient temperature of approximately $30^{\circ} \mathrm{C}$ (Fig. 3d), implying dry and hot conditions during the particle growth period. The observed mixing ratio of $\mathrm{O}_{x}\left(\mathrm{NO}_{2}+\mathrm{O}_{3}\right)$ largely increased from $\sim 60$ to $\sim 130 \mathrm{ppb}$ during the growth period, supporting the photochemical formation of secondary species to drive particle growth.

As mentioned above, the growth of newly formed particles is mainly attributed to sulfuric acid, ammonium nitrate, and secondary organic compounds (Wiedensohler et al., 2009; Riipinen et al., 2011; Zhang et al., 2012; Ehn et al., 2014; Man et al., 2015; Wang et al., 2015, 2020; Burkart et al., 2017; Lee et al., 2019). We therefore explore their respective contributions as follows. First, we calculated the contribution of sulfuric acid to the growth based on the observed mixing ratio of $\mathrm{SO}_{2}$ and Eqs. (2)-(4). Second, we examined whether $\mathrm{NH}_{4} \mathrm{NO}_{3}$ freshly formed in $\mathrm{PM}_{1.0}$ or $\mathrm{PM}_{2.5}$ during the particle growth period. In the case of no $\mathrm{NH}_{4} \mathrm{NO}_{3}$ formation, its contribution would not be expected. This is because an even higher product of $\mathrm{HNO}_{3 \text { gas }} \times \mathrm{NH}_{3 \text { gas }}$ is required to overcome the Kelvin effect and form $\mathrm{NH}_{4} \mathrm{NO}_{3}$ in nucleation mode and Aitken mode particles. Thus, the growth unexplained by sulfuric acid should be mainly contributed by SOA. Third, in the case of $\mathrm{NH}_{4} \mathrm{NO}_{3}$ formation, we compared the net increase in $\mathrm{NH}_{4} \mathrm{NO}_{3}$ with that in SOA. It is noteworthy that this approach is limited by the uncertainty in explaining the growth because the ratios of increased $\mathrm{NH}_{4} \mathrm{NO}_{3}$ over increased SOA in $\mathrm{PM}_{1.0}$ or $\mathrm{PM}_{2.5}$ may not be the same as the ratios in nucleation mode and Aitken mode particles. In this case, the required mass of $\mathrm{NH}_{4} \mathrm{NO}_{3}$ or $\mathrm{SOA}$ to the growth was also estimated and compared with their respective net increases to facilitate the analysis.

Based on the observed mixing ratio of $\mathrm{SO}_{2}$ shown in Fig. 3b and Eqs. (2)-(4), sulfuric acid was estimated to contribute $<2 \%$ to particle growth during the whole NPF period. Almost constant concentrations of $\mathrm{NO}_{3}^{-}$and $\mathrm{NH}_{4}^{+}$were observed at 11:00-14:00, implying that fresh $\mathrm{NH}_{4} \mathrm{NO}_{3}$ formation did not occur before 14:00 (Fig. 3c). Therefore, SOA was the dominant contributor to particle growth before 14:00, as supported by the decrease in the hygroscopicity parameter of $50 \mathrm{~nm}$ atmospheric particles from $\sim 0.3$ to $\sim 0.1$ during the same event, independently reported by $\mathrm{Wu}$ et al. (2016). From 14:00 to 16:00, the concentrations of $\mathrm{NO}_{3}^{-}$and $\mathrm{NH}_{4}^{+}$ significantly increased, accompanied by an increase in OOA by $11 \mu \mathrm{g} \mathrm{m}^{-3}$. Assuming an increase in $\mathrm{NO}_{3}^{-}$because of the formation of $\mathrm{NH}_{4} \mathrm{NO}_{3}$, the net increase in $\mathrm{NH}_{4} \mathrm{NO}_{3}$ was $10 \mu \mathrm{g} \mathrm{m}^{-3}$. Thus, the formation of $\mathrm{NH}_{4} \mathrm{NO}_{3}$ may also play an important role in the growth of new particles after 14:00. Zhu et al. (2014) and Man et al. (2015) reported that $\mathrm{NH}_{4} \mathrm{NO}_{3}$ can be an important contributor to the growth of new particles (from $40-50 \mathrm{~nm}$ to a larger size at night). Supposing that the particle growth during the entire growth period from 11:00 to 16:00 was completely driven by SOA, the required amount was estimated as $8.9 \mu \mathrm{g} \mathrm{m}^{-3}$. The observed concentration of OOA in $\mathrm{PM}_{1.0}$ increased by $15.5 \mu \mathrm{g} \mathrm{m}^{-3}$ during the growth period, which could reasonably satisfy the required amount. Note that only secondary organic compounds of low volatility can support the growth of small particles, and those 

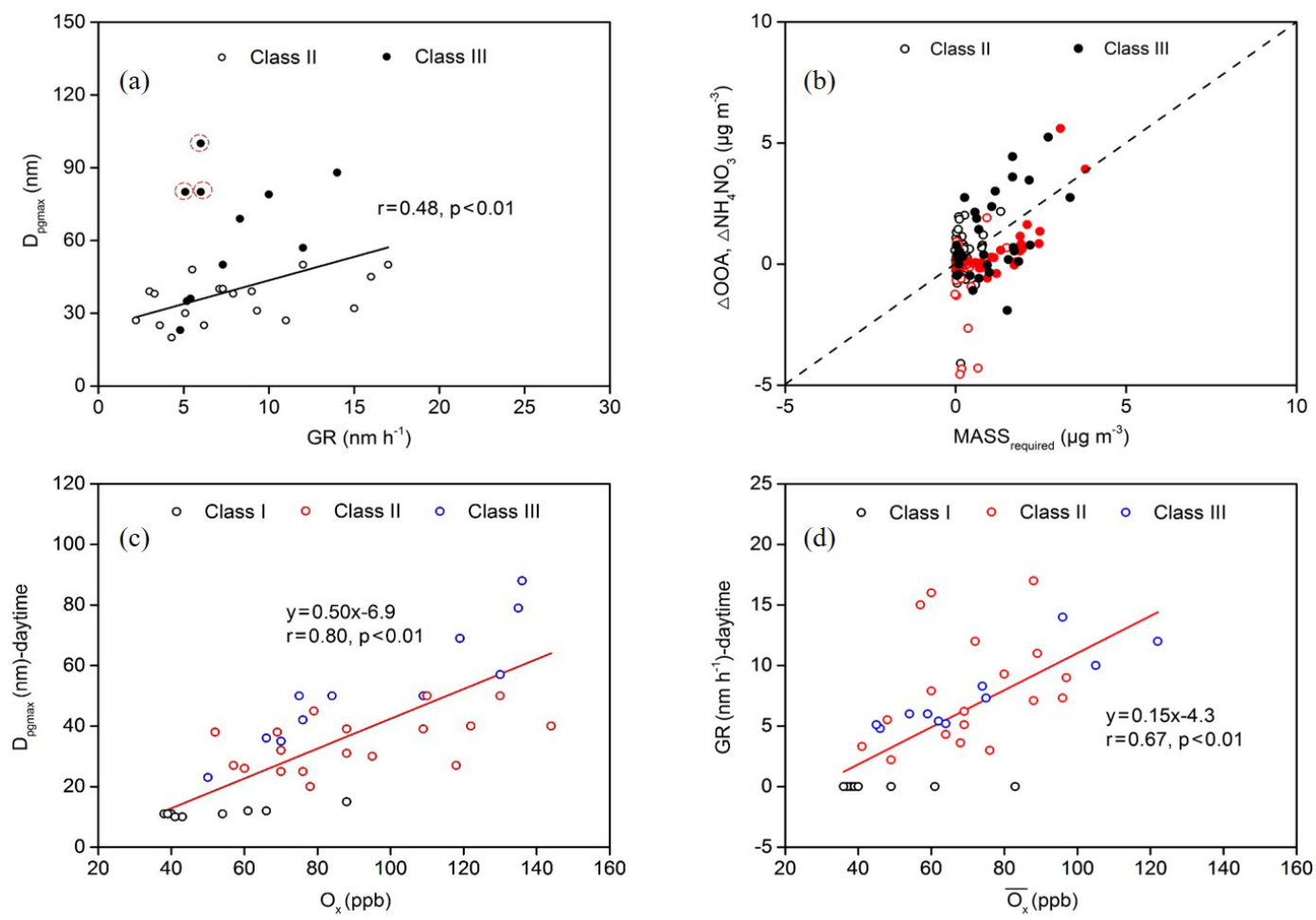

Figure 6. Relationship between $D_{\text {pgmax }}$ and GR (a). Hourly variations in measured OOA (black mark) and $\mathrm{NH}_{4} \mathrm{NO}_{3}$ (red mark, assuming $\mathrm{NO}_{3}^{-}$to be completely associated with $\mathrm{NH}_{4}^{+}$) versus required masses of OOA and $\mathrm{NH}_{4} \mathrm{NO}_{3}$ for corresponding particle growth (b). Relationship between $D_{\text {pgmax }}$ in the daytime and the corresponding maximum $\mathrm{O}_{x}(\mathbf{c})$. Relationship between GRs in the daytime and the average mixing ratio of $\mathrm{O}_{x}(\mathbf{d})$.

of high volatility may also contribute to the growth of large particles (Ehn et al., 2014; Burkart et al., 2017). The growth of new particles stopped after 15:54 until the new particle signal gradually disappeared at $\sim 20: 00$. The observed concentrations of OOA and $\mathrm{NO}_{3}^{-}$did not increase during the $4 \mathrm{~h}$, although they largely oscillated.

Another example of one-stage growth occurred on $25 \mathrm{Au}-$ gust 2014, and newly formed particles took the longest time to reach $D_{\text {pgmax }}$ (Fig. 3e). RH was lower than $50 \%$, and the ambient air temperature varied from 24 to $31^{\circ} \mathrm{C}$ during the growth period (Fig. $3 \mathrm{~h}$ ), also indicating dry and hot conditions during the particle growth period. The NPF event was observed from 07:50 on 25 August 2014 to 08:00 the next day. The new particle signal was unstable in the initial $3 \mathrm{~h}$ because of the spatial heterogeneity of NPF.

The $D_{\mathrm{pg}}$ of newly formed particles started to increase from $12 \mathrm{~nm}$ at $10: 48$ to $80 \mathrm{~nm}$ at 24:00 with a particle growth rate of $5.1 \mathrm{~nm} \mathrm{~h}^{-1}$. During the period of 11:00-19:00, sulfuric acid contributed to only $6 \%$ of the increase in $D_{\mathrm{pg}}$ from 12 to $51 \mathrm{~nm}$ on the basis of the observed mixing ratios of $\mathrm{SO}_{2}$. Because of the lack of photochemical reactions, concentrations of sulfuric acid should have been much lower during nighttime than during daytime (Petäjä et al., 2009; Lu et al., 2019).
No measured concentrations of particulate chemical species were available on that day. Their modeled concentrations in $\mathrm{PM}_{2.5}$ were alternatively used to argue possible contributors to the growth of newly formed particles, although the uncertainty may be even larger than the use of measured particulate species in $\mathrm{PM}_{1.0}$. The modeled concentrations of $\mathrm{NH}_{4}^{+}$and $\mathrm{NO}_{3}^{-}$were almost constant at 11:00-18:00 (Fig. $3 \mathrm{~g}$ ), suggesting that $\mathrm{NH}_{4} \mathrm{NO}_{3}$ did not freshly form to drive particle growth. Thus, SOA likely acted as the dominant contributor to particle growth.

The modeled net increase in particulate $\mathrm{NH}_{4} \mathrm{NO}_{3}$ was $3.6 \mu \mathrm{g} \mathrm{m}^{-3}$ from 18:00 to 22:00, with the $D_{\mathrm{pg}}$ of newly formed particles increasing from 47 to $70 \mathrm{~nm}$ (Fig. 3g). Assuming that the new particle growth from 18:00 to 22:00 was completely driven by $\mathrm{NH}_{4} \mathrm{NO}_{3}$, the required amount was estimated to be $3.1 \mu \mathrm{g} \mathrm{m}^{-3}$. Thus, $\mathrm{NH}_{4} \mathrm{NO}_{3}$ may have contributed significantly to particle growth in this period. Although the modeled concentrations of SOA increased (Fig. 3g), the uncertainty of the modeled values cannot allow for quantifying its contribution. The $D_{\mathrm{pg}}$ of newly formed particles increased from 70 to $\sim 80 \mathrm{~nm}$ from $22: 00$ to $24: 00$ when the modeled concentrations of all species decreased because of the dilution effect. Afterwards, the new particles stopped growing until their signal gradually disappeared at 08:00 on the next day. The modeled concentrations of 
$\mathrm{NH}_{4} \mathrm{NO}_{3}$ and SOA were almost constant after 01:00 the next day, consistent with the lack of apparent growth in these large new particles.

During the two NPF events on 12 and 13 July, sulfuric acid vapor was estimated as a minor contributor to particle growth (Fig. S3). The modeled results suggested that $\mathrm{NH}_{4} \mathrm{NO}_{3}$ were important contributors to particle growth only at nighttime (Fig. S4c, g). This left SOA as the major contributor to particle growth in daytime, but its contribution at nighttime was still unclear. Nevertheless, the concentrations of chemical species in nanometer particles of various sizes are required to confirm this.

\subsection{Two-stage new particle growth-A pattern to $\mathrm{CCN}$ size}

Figures 4 and S5 show that the final $D_{\text {pgmax }}$ values of newly formed particles were $75,115,75$, and $110 \mathrm{~nm}$ on 27 June and 6, 12, and 15 August 2014, respectively. On 27 June 2014 (Fig. 4a-d), the NPF events were first observed at 09:00 and lasted for $18 \mathrm{~h}$, with RH generally lower than $40 \%$. Apparent growth of newly formed particles could not be observed from 09:00 to 10:30. The $D_{\text {pg }}$ of newly formed particles increased from $\sim 10 \mathrm{~nm}$ at $10: 30$ to $35 \mathrm{~nm}$ at 15:20, with a GR of $5.2 \mathrm{~nm} \mathrm{~h}^{-1}$. Using the observed mixing ratio of $\mathrm{SO}_{2}$, sulfuric acid vapor was estimated to contribute to the first-stage particle growth by $3 \%$ (Fig. $4 \mathrm{~b}$ ). The constant concentrations of $\mathrm{NO}_{3}^{-}$observed during this period implied that $\mathrm{NH}_{4} \mathrm{NO}_{3}$ did not freshly form (Fig. 4c). Again, particle growth during the period, which could not be explained by sulfuric acid, should be completely driven by SOA. The required amount of SOA was estimated to be as low as $0.56 \mu \mathrm{g} \mathrm{m}^{-3}$. The observed OOA fluctuated at $5-6 \mu \mathrm{g} \mathrm{m}^{-3}$ during that period (Fig. 4c).

After 15:20, the $D_{\mathrm{pg}}$ of newly formed particles stopped growing and fluctuated at approximately $35 \mathrm{~nm}$ for approximately $2 \mathrm{~h}$. The first-stage particle growth apparently encountered an upper limit. Compared with the concentrations observed before and after the $2 \mathrm{~h}$ period, the significantly decreased number concentrations of newly formed particles imply spatial heterogeneity of NPF on that day. In other words, much weaker atmospheric nucleation generated new particles in the upwind atmosphere within a certain spatial range, and the grown new particles at a lower number concentration were transported and observed at the rooftop site at 15:2017:40. The slightly decreased mixing ratios of $\mathrm{O}_{x}$ during this time, which were unexpected considering a sharp increase in the observed $\mathrm{O}_{x}$ after the period, imply reduced photochemical-reaction activities in the upwind atmosphere at certain spatial ranges. The photochemical-reaction activities during this period may be too weak to generate sufficient amounts of secondary organic and inorganic precursors to support the growth of new particles $>35 \mathrm{~nm}$ to a larger size, and thus the growth encountered the upper limit, as shown in the diagram in the graphical abstract.
After 17:40, the $D_{\text {pg }}$ of newly formed particles started to increase from 32 to $75 \mathrm{~nm}$ at 22:30, with a GR of $9.7 \mathrm{~nm} \mathrm{~h}^{-1}$, which nearly doubled the growth rate observed during the first growth stage. The observed mixing ratio of $\mathrm{O}_{x}$ increased from $66 \mathrm{ppb}$ at 17:20 to $\sim 90 \mathrm{ppb}$ at 21:20, supporting the secondary formation of chemical species to drive particle growth (Fig. 4b). The observed concentrations of OOA (left axis) and $\mathrm{NO}_{3}^{-}$(right axis) rapidly increased from 18:00 to 22:20, with the former being approximately 4 times larger than the latter. The required amount of $\mathrm{NH}_{4} \mathrm{NO}_{3}$ for particle growth during the period was estimated to be $5.3 \mu \mathrm{g} \mathrm{m}^{-3}$, while the net increase in $\mathrm{NH}_{4} \mathrm{NO}_{3}$ was $1.6 \mu \mathrm{g} \mathrm{m}^{-3}$. SOA may dominate the growth of new particles. Lee et al. (2016) and Huang et al. (2019) recently reported that highly functionalized organonitrates generated from the reaction of $\mathrm{NO}_{3}$ free radicals with organics can contribute to the growth of particles at nighttime. After 22:30, the new particles stopped growing until their signal gradually disappeared at 03:00 on the next day.

Following the analysis mentioned above, freshly formed SOA was argued to dominantly drive the first-stage particle growth on 6 August (Fig. 4e) and 12, and 15 August 2014 (Fig. S5). On the other hand, newly formed $\mathrm{NH}_{4} \mathrm{NO}_{3}$ likely acted as an important contributor to second-stage particle growth. Again, large uncertainties in modeled concentrations may exist because of the lack of direct measurements of chemical species in nanometer particles of various sizes.

\subsection{Two-stage new particle growth-B pattern to $\mathrm{CCN}$ size}

Among the three two-stage growth-B NPF events, the longest shrinkage (approximately $4 \mathrm{~h}$ ) in grown new particles occurred on 23 June 2014 (Fig. 5a). According to our analysis, the first-stage particle growth on that day was driven by SOA because the estimated sulfuric acid and observed $\mathrm{NO}_{3}^{-}$plus $\mathrm{NH}_{4}^{+}$yielded either a small percentage or negligible contribution to particle growth. The $D_{\mathrm{pg}}$ of newly formed particles increased from $17 \mathrm{~nm}$ at 11:20 to $79 \mathrm{~nm}$ at 17:20, with a GR of $10 \mathrm{~nm} \mathrm{~h}^{-1}$. From 11:20 to 17:20, the mixing ratio of $\mathrm{O}_{x}$ increased from 74 to $122 \mathrm{ppb}$ (Fig. 5b). The net increase in the observed OOA was $12.2 \mu \mathrm{g} \mathrm{m}^{-3}$ during this period (Fig. 5c), while the required amount of SOA was estimated as $4.1 \mu \mathrm{g} \mathrm{m}^{-3}$. SOA was very likely to be the major contributor to particle growth in this period. As independently reported by Wu et al. (2016), the hygroscopicity parameter of $50 \mathrm{~nm}$ atmospheric particles decreased from $\sim 0.15$ to $\sim 0.05$ during the same event.

The $D_{\mathrm{pg}}$ of newly formed particles stopped growing at $79 \mathrm{~nm}$ from 17:20 through 18:00 and then decreased from 79 to $52 \mathrm{~nm}$ at 21:22, with a decrease rate of $8 \mathrm{~nm} \mathrm{~h}^{-1}$. During this period of shrinkage, the observed mixing ratio of $\mathrm{O}_{x}$ largely decreased from 130 to $80 \mathrm{ppb}$, and the observed OOA decreased from 16.2 to $11.4 \mu \mathrm{g} \mathrm{m}^{-3}$ (Fig. $5 \mathrm{~b}-\mathrm{c}$ ). However, the concentrations of $\mathrm{NH}_{4}^{+}$were almost constant. A reparti- 
tion of the semivolatile SOA in gas and particle phases was hypothesized to cause the evaporation of semivolatile SOA to the gas phase. The shrinkage may also be argued as being attributable to the spatial heterogeneity of NPF, but modeling of size-segregated number concentration is required to confirm this.

After 21:22, $D_{\text {pg }}$ restarted to increase from $\sim 50$ to $90 \mathrm{~nm}$ over $4 \mathrm{~h}$. The formation of $\mathrm{NH}_{4} \mathrm{NO}_{3}$ likely yielded an important contribution to the second stage of particle growth - a net observed increase of $4.5 \mu \mathrm{g} \mathrm{m}^{-3}$ versus the required amount of $8.4 \mu \mathrm{g} \mathrm{m}^{-3}$. SOA may also contribute to the second stage of particle growth according to a net increase in OOA by $1.5 \mu \mathrm{g} \mathrm{m}^{-3}$ (Fig. 5c). After the second stage of growth, the $D_{\text {pg }}$ of new particles experienced small oscillations at $\sim 90 \mathrm{~nm}$ until the signal was overwhelmed completely by aged plumes.

Following similar observations on 23 June, reduced photochemical-reaction activities were also argued to cause the shrinkage in newly formed particles on 11 June and 26 July 2014 (Fig. S6). The observed and modeled results for the $2 \mathrm{~d}$ imply that $\mathrm{NH}_{4} \mathrm{NO}_{3}$ played an important role in new particle growth only at night. In the daytime, SOA likely acted as the major contributor.

\subsection{Statistical analysis of factors related to new particle growth}

The growth rate of newly formed particles is an intensity quantity and mainly determined by the concentrations of condensable vapors such as sulfuric acid, organics of various volatilities, nitric acid, and ammonia (Zhang et al., 2012; Ehn et al., 2014; Man et al., 2015; Lee et al., 2019). In contrast, $D_{\text {pgmax }}$ values are determined by the total amount of vapors condensed on grown new particles (an extensive quantity), which may or may not have a positive correlation with the concentrations of these vapors (Zhu et al., 2019). The values of $D_{\text {pgmax }}$ were plotted against those of GR in Fig. 6a (two variables during the first growth period were used to determine the occurrence of two-stage particle growth) and found to be widely scattered with $r=0.23$. When three circled points were excluded, $D_{\text {pgmax }}$ was significantly correlated with GR, but the $r$ value was still as low as 0.48 (Fig. 6a). GR alone is not sufficient to characterize the growth of newly formed particles considering their potential impacts on the climate, and both $D_{\text {pgmax }}$ and GR should be alternatively used.

As mentioned above, SOA and $\mathrm{NH}_{4} \mathrm{NO}_{3}$ are likely two major contributors to particle growth in different periods of NPF events, with small contributions of sulfuric acid. Figure $6 \mathrm{~b}$ shows the net hourly increases in OOA and $\mathrm{NH}_{4} \mathrm{NO}_{3}$ against the hourly required masses for particle growth, assuming densities of $1.5 \mu \mathrm{g} \mathrm{m}^{-3}$ for OOA and $1.7 \mu \mathrm{g} \mathrm{m}^{-3}$ for $\mathrm{NH}_{4} \mathrm{NO}_{3}$. Both OOA and $\mathrm{NH}_{4} \mathrm{NO}_{3}$ generally increase with increasing required masses and reasonably satisfy the required masses, but they are largely scattered in Fig. 6b. It remains challenging to accurately quantify the contributors to the growth of newly formed particles.

The generation of $\mathrm{OOA}$ and $\mathrm{HNO}_{3}$ is strongly related to oxidation reactions during the daytime. Thus, we further plotted $D_{\text {pgmax }}$ and GR against $\mathrm{O}_{x}\left(\mathrm{O}_{x}=\mathrm{NO}_{2}+\mathrm{O}_{3}\right)$ in the particle growth period during the daytime. Figure $6 \mathrm{c}$ shows a good correlation between $D_{\text {pgmax }}$ and $\mathrm{O}_{x}$ (hourly average value when $D_{\text {pgmax }}$ reached) with $r=0.80$ and $p<0.01$. The values of $\mathrm{O}_{x}$ in class I NPF events were significantly smaller than those in class II and class III with $p<0.05$, and the lower $\mathrm{O}_{x}$ could be one of the factors for the lack of apparent particle growth in class I. In addition, there was no significant difference in $\mathrm{O}_{x}$ between class II and class III. Including $\mathrm{O}_{x}$, other factors, such as condensational sink, should also affect the particle growth in class I, II, and III NPF events (Guo et al., 2020). Figure 6d shows a significant correlation between GR and $\mathrm{O}_{x}$ (average value during the entire growth period) with $r=0.67$ and $p<0.01$. The decreased $r$ value implies that the response of GR to the increase in $\mathrm{O}_{x}$ is highly variable.

Oxidation products of biogenic VOCs, such as highly oxygenated molecules (HOMs), have been reportedly overwhelmed to determine the condensation growth of newly formed particles in the small size range because of their low volatilities (Ehn et al., 2014; Lee et al., 2019). In this study, the clear seasonal boundary of class I and class II + III NPF events - for example, $100 \%$ of class I events in winter versus $7 \%$ and $93 \%$ of class I and class II + III events in summer - also points toward the importance of oxidation products of biogenic VOCs in particles growing from $\sim 10 \mathrm{~nm}$ to larger sizes. In the summertime, theoretically increased emissions of biogenic VOCs and enhanced photochemical reactions indicated by $\mathrm{O}_{x}$ are expected to generate more HOMs for the growth of particles from $\sim 10 \mathrm{~nm}$ to larger sizes. In spring, approximately half of the NPF events are subject to class I. However, there were no class III events. The distinctive seasonal particle growth patterns may further imply that the amount of oxidation products of biogenic VOCs not only determines the growth of new particles from $\sim 10 \mathrm{~nm}$ to larger sizes but also CCN size. However, direct measurements of HOMs in small-sized nanoparticles were unavailable to support this argument. In fact, such measurements remain challenging among the research community, as reviewed by Lee et al. (2019).

\subsection{SP during class III NPF events}

The potential contribution of new particles to the population of CCN was evaluated using the calculated SP. For class III NPF events, the final SPs are listed in Table 1. For example, in the one-stage growth NPF event on 25 August 2014 (Fig. S2a-b), $N_{50-200 \mathrm{~nm}}$ gradually decreased from $\sim 05: 00$ to $\sim 11: 00$ and reached the lowest values of $787 \pm 120 \mathrm{~cm}^{-3}$ at 10:18-11:59. $N_{50-200 \mathrm{~nm}}$ then increased with the growth of newly formed particles. It reached the highest values of 
$9210 \pm 257 \mathrm{~cm}^{-3}$ at 19:47-20:17 if a few spikes afterwards were not considered. The spikes were more likely due to the intrusion of plumes rather than the new particle signal. The lowest values over $0.5 \mathrm{~h}$ were considered to be the regional background. The mean of the highest values over $0.5 \mathrm{~h} \mathrm{mi-}$ nus the mean of the lowest values was considered as the net maximum number concentration of grown new particles beyond $50 \mathrm{~nm}$, which was $8.4 \times 10^{3} \mathrm{~cm}^{-3}$. Thus, $\mathrm{SP}_{50 \mathrm{~nm}}$ was estimated to be $35 \%$. Using a similar approach as shown in Fig. S2b, the net maximum number concentration of grown new particles beyond $70 \mathrm{~nm}$ was $4.7 \times 10^{3} \mathrm{~cm}^{-3}$, and the estimated $\mathrm{SP}_{70 \mathrm{~nm}}$ was $20 \%$. In the two-stage new particle growth on 27 June 2014 (Fig. 4a), the net maximum number concentration of grown new particles beyond $50 \mathrm{~nm}$ reached a maximum value of $9.0 \times 10^{3} \mathrm{~cm}^{-3}$, with the estimated $\mathrm{SP}_{50 \mathrm{~nm}}$ being $60 \%$. Using the same method, $\mathrm{SP}_{70 \mathrm{~nm}}$ was estimated to be $39 \%$.

Overall, in class III NPF events, $\mathrm{SP}_{50}$ varied from $35 \%$ to $60 \%$, with a median of $50 \%$. Meanwhile, $\mathrm{SP}_{70}$ varied from $20 \%$ to $44 \%$, with a median of $32 \%$. Our results imply that an appreciable fraction of new particles can grow to $\mathrm{CCN}$ size prior to being removed by atmospheric processes. Considering that high SS occasionally occurs in the atmosphere (Fan et al., 2018), new particles with $D_{\mathrm{pg}}$ increasing up to $50 \mathrm{~nm}$ may also be activated as CCN. Thus, $>30 \%$ of new particles in 11 out of 27 NPF events in the summer of 2014 can reach $50 \mathrm{~nm}$ and may eventually contribute to the population of $\mathrm{CCN}$.

\subsection{Spatial heterogeneity of NPF}

The spatial heterogeneity of NPF can be clearly identified using high-time-resolution measurements. Two NPF events were used as examples to demonstrate the spatial heterogeneity.

The NPF event on 6 August 2014 (Fig. 4e) clearly exhibited spatial heterogeneity; the signal of new particles largely dropped to a negligible level approximately $1 \mathrm{~h}$ after 11:37 and then increased to a detectable level (Fig. 4e). At approximately $17: 40, D_{\text {pg }}$ jumped from 25 to $50 \mathrm{~nm}$ within $5 \mathrm{~min}$, indicating a large spatial heterogeneity before and after 17:40-17:50. New particles observed after 17:51 were hypothesized to experience a growth similar to the trend in the white dashed line (Fig. 4e) in the upwind atmosphere during the period from 11:37 to 17:51.

Moreover, both the number concentrations and $D_{\mathrm{pg}}$ of new particles exhibited an inverted bell shape at 23:00-01:51 on 6-7 August 2014 (Fig. 4e). The inverted bell shape very likely reflects the spatial heterogeneity of NPF in the upwind atmosphere at a certain spatial range. The new particle signal was clearly enhanced after 01:51 on 7 August 2014. The new particles observed after the time were hypothesized to experience a growth similar to the trend in the white dashed line (Fig. 4e) in the upwind atmosphere.
The NPF event on 23 June also exhibited clear spatial heterogeneity (Fig. 5a). From 12:00 to $18: 00, N_{8-200 \mathrm{~nm}}$ oscillated at $1.2 \pm 0.2 \times 10^{4} \mathrm{~cm}^{-3}$ (Fig. 5b). In approximately $20 \mathrm{~min}, N_{8-200 \mathrm{~nm}}$ increased to a higher level and then oscillated at $1.5 \pm 0.2 \times 10^{4} \mathrm{~cm}^{-3}$ from 18:20 on 23 June to $01: 30$ on 24 June. $N_{8}-200 \mathrm{~nm}$ then oscillated at $1.0 \pm 0.1 \times 10^{4} \mathrm{~cm}^{-3}$ from 01:50 to $04: 15$ on 24 June.

Based on the time series of new particle number concentrations and their sizes observed, the spatial heterogeneity of NPF can be inferred to have occurred universally in each NPF event. This phenomenon should be considered for accurately evaluating the climate impacts of NPF events.

\section{Conclusions}

In this study, we investigated 46 NPF events in Beijing's urban atmosphere through three campaigns, with particular attention to the growth behaviors of newly formed particles. First, we found seasonal variations in the maximum sizes of newly grown particles. For instance, $D_{\text {pgmax }}$ was found to exceed $75 \mathrm{~nm}$ in 11 out of $27 \mathrm{NPF}$ events in summer. However, no apparent growth in new particles with $D_{\text {pgmax }}<20 \mathrm{~nm}$ was observed in December across all events, which could be attributed to several factors, such as the lower level of $\mathrm{O}_{x}$ and high condensation sink. Correlation analyses also suggest that the concentrations of $\mathrm{O}_{x}$ may play an important role in determining $D_{\text {pgmax }}$. This finding may allow us to rethink the seasonal impacts of NPF events on the climate in Beijing and other urban areas in northern China.

According to the observed mixing ratio of $\mathrm{SO}_{2}$, sulfuric acid vapor generally yielded minor contributions to the growth of new particles. The observed and modeled concentrations of particulate chemical species suggested that the growth of newly formed particles during the daytime was mainly caused by OOA (or SOA). At night and during the late afternoon, the increased amount of $\mathrm{NH}_{4} \mathrm{NO}_{3}$ can reasonably support new particle growth in most class III NPF events. Secondary organics were also an important contributor to nighttime new particle growth in class III NPF events with OOA to be observed, but its contribution was still unclear in cases absent of OOA observations. Nevertheless, direct measurements of secondary organics in nanometer particles of different sizes are required to confirm their contribution.

To verify the climate impacts of NPF events, $\mathrm{SP}_{50}$ and the final $\mathrm{SP}_{70}$ need to be quantified. In class III NPF events, $\mathrm{SP}_{50}$ and the final $\mathrm{SP}_{70}$ varied from $35 \%$ to $60 \%$ and from $20 \%$ to $44 \%$, respectively, implying that an appreciable fraction of new particles can grow to $\mathrm{CCN}$ size. Our observations also indicated that each NPF event exhibited spatial heterogeneity to some extent, which may be attributable to varying photochemical-reaction activities. When photochemicalreaction activities are low, the growth of new particles may reach an upper limit or even decline. These factors should 
also be considered for accurately evaluating the climate impacts of NPF events in the future.

Data availability. The research data can be accessed upon contact with the corresponding authors, Xiaohong Yao (xhyao@ouc.edu.cn) and Yujiao Zhu (zhuyujiao@sdu.edu.cn).

Supplement. The supplement related to this article is available online at: https://doi.org/10.5194/acp-21-183-2021-supplement.

Author contributions. XY designed the research. YZ, MZ, and YS conducted the field measurements. $\mathrm{LH}$ and $\mathrm{XL}$ ran the CMAQ model. LM and YZ analyzed the data and wrote the paper. YG, YS, $\mathrm{HG}$, and $\mathrm{XY}$ helped to interpret the results. $\mathrm{XY}$ revised the original draft of the paper. All authors contributed toward improving the paper.

Competing interests. The authors declare that they have no conflict of interest.

Acknowledgements. This research was supported by the National Key Research and Development Program in China (grant no. 2016YFC0200504) and the Natural Science Foundation of China (grant nos. 41576118 and 41430646).

Financial support. This research has been supported by the National Key Research and Development Program in China (grant no. 2016YFC0200500) and the National Natural Science Foundation of China (grant nos. 41776086 and 41430646).

Review statement. This paper was edited by Stefania Gilardoni and reviewed by two anonymous referees.

\section{References}

Asmi, E., Kivekäs, N., Kerminen, V.-M., Komppula, M., Hyvärinen, A.-P., Hatakka, J., Viisanen, Y., and Lihavainen, H.: Secondary new particle formation in Northern Finland Pallas site between the years 2000 and 2010, Atmos. Chem. Phys., 11, 12959-12972, https://doi.org/10.5194/acp-11-12959-2011, 2011.

Baek, J., Hu, Y. T., Odman, M. T., and Russell, A. G.: Modeling secondary organic aerosol in CMAQ using multigenerational oxidation of semi-volatile organic compounds, J. Geophys. Res., 116, D22204, https://doi.org/10.1029/2011JD015911, 2011.

Brean, J., Harrison, R. M., Shi, Z., Beddows, D. C. S., Acton, W. J. F., Hewitt, C. N., Squires, F. A., and Lee, J.: Observations of highly oxidized molecules and particle nucleation in the atmosphere of Beijing, Atmos. Chem. Phys., 19, 14933-14947, https://doi.org/10.5194/acp-19-14933-2019, 2019.
Burkart, J., Hodshire, A. L., Mungall, E. L., Pierce, J. R., Collins, D. B., Ladino, L. A., Lee, A. K., Irish, V., Wentzell, J. J., Liggio, J., and Papakyriakou, T.: Organic condensation and particle growth to $\mathrm{CCN}$ sizes in the summertime marine Arctic is driven by materials more semivolatile than at continental sites, Geophys. Res. Lett., 44, 10725-10734, https://doi.org/10.1002/2017GL075671, 2017.

Byun, D. and Schere, K.L.: Review of the Governing Equations, Computational Algorithms, and Other Components of the Models-3 Community Multiscale Air Quality (CMAQ) Modeling System, Appl. Mech. Rev., 59, 51-77, https://doi.org/10.1115/1.2128636, 2006.

Chen, X., Yang, W., Wang, Z., Li, J., Hu, M., An, J., Wu, Q., Wang, Z., Chen, H., Wei, Y., Du, H., and Wang, D.: Improving new particle formation simulation by coupling a volatility-basis set (VBS) organic aerosol module in NAQPMS+APM, Atmos. Environ., 204, 1-11, https://doi.org/10.1016/j.atmosenv.2019.01.053, 2019.

Chu, B., Kerminen, V.-M., Bianchi, F., Yan, C., Petäjä, T., and Kulmala, M.: Atmospheric new particle formation in China, Atmos. Chem. Phys., 19, 115-138, https://doi.org/10.5194/acp-19-1152019, 2019.

Dal Maso, M., Kulmala, M., Riipinen, I., Wagner, R., Hussein, T., Aalto, P. P., Lehtinen, K. E. J.: Formation and growth of fresh atmospheric aerosols: eight years of aerosol size distribution data from SMEAR II, Hyytiälä, Finland. Boreal Env. Res., 10, 323 336, 2005.

Du, W., Zhao, J., Wang, Y., Zhang, Y., Wang, Q., Xu, W., Chen, C., Han, T., Zhang, F., Li, Z., Fu, P., Li, J., Wang, Z., and Sun, Y.: Simultaneous measurements of particle number size distributions at ground level and $260 \mathrm{~m}$ on a meteorological tower in urban Beijing, China, Atmos. Chem. Phys., 17, 6797-6811, https://doi.org/10.5194/acp-17-6797-2017, 2017.

Dusek, U., Frank, G. P., Hildebrandt, L., Curtius, J., Schneider, J., Walter, S., Chand, D., Drewnick, F., Hings, S., Jung, D., Borrmann, S., and Andreae, M. O: Size matters more than chemistry for cloud-nucleating ability of aerosol particles, Science, 312, 1375-1378, https://doi.org/10.1126/science.1125261, 2006.

Ehn, M., Thornton, J. A., Kleist, E., Sipilä, M., Junninen, H., Pullinen, I., Springer, M., Rubach, F., Tillmann, R., Lee, B., Lopez-Hilfiker, F., Andres, S., Acir, I., Rissanen, M., Jokinen, T., Schobesberger, S., Kangasluoma, J., Kontkanen, J., Nieminen, T., Kurtén, T., Nielsen, L. B., Jørgensen, S., Kjaergaard, H. G., Canagaratna, M., Maso, M. D., Berndt, T., Petäjä, T., Wahner, A., Kerminen, V., Kulmala, M., Worsnop, D. R., Wildt, J., and Mentel, T. F.: A large source of lowvolatility secondary organic aerosol, Nature, 506, 476-479, https://doi.org/10.1038/nature13032, 2014.

Fan, J., Rosenfeld, D., Zhang, Y., Giangrande, S. E., Li, Z., Machado, L. A. T., Martin, S. T., Yang, Y., Wang, J., Artaxo, P., Barbosa, H. M. J., Braga, R. C., Comstock, J. M., Feng, Z., Gao, W., Gomes, H. B., Mei, F., Pöhlker, C., Pöhlker, M. L., Pöschl, U., Souza, R. A. F.: Substantial convection and precipitation enhancements by ultrafine aerosol particles, Science, 359, 411-418, 2018.

Gordon, H., Kirkby, J., Baltensperger, U., Bianchi, F., Breitenlechner, M., Curtius, J., Dias, A., Dommen, J., Donahue, N. M., Dunne, E. M., Duplissy, J., Ehrhart, S., Flagan, R. C., Frege, C., Fuchs, C., Hansel, A., Hoyle, C. R., Kul- 
mala, M., Kürten, A., Lehtipalo, K., Makhmutov, V., Molteni, U., Rissanen, M. P., Stozkhov, Y., Tröstl, J., Tsagkogeorgas, G., Wagner, R., Williamson, C., Wimmer, D., Winkler, P. M., Yan, C., and Carslaw, K .S.: Causes and importance of new particle formation in the present-day and preindustrial atmospheres, J. Geophys. Res.-Atmos., 122, 8739-8760, https://doi.org/10.1002/2017JD026844, 2017.

Guenther, A., Karl, T., Harley, P., Wiedinmyer, C., Palmer, P. I., and Geron, C.: Estimates of global terrestrial isoprene emissions using MEGAN (Model of Emissions of Gases and Aerosols from Nature), Atmos. Chem. Phys., 6, 3181-3210, https://doi.org/10.5194/acp-6-3181-2006, 2006.

Guo, S., Hu, M., Zamora, M. L., Peng, J., Shang, D., Zheng, J., Du, Z., Wu, Z., Shao, M., Zeng, L., Molina, M. J., and Zhang, R.: Elucidating severe urban haze formation in China, P. Natl. Acad. Sci. USA, 111, 17373-17378, https://doi.org/10.1073/pnas.1419604111, 2014.

Guo, S., Hu, M., Peng, J., Wu, Z., Zamora, M. L., Shang, D., Du, Z., Zheng, J., Fang, X., Tang, R., Wu, Y., Zeng, L., Shuai, S., Zhang, W., Wang, Y., Ji, Y., Zhang, A., Wang, W., Zhang, F., Zhao, J., Gong, X., Wang, C., Molina, M., and Zhang, R.: Remarkable nucleation and growth of ultrafine particles from vehicular exhaust, P. Natl. Acad. Sci., 117, 3427-3432, https://doi.org/10.1073/pnas.1916366117, 2020.

He, K. B., Yang, F. M., Ma, Y. L., Zhang, Q., Yao, X. H., Chan, C. K., Cadle, S., Chan, T., and Mulawa, P.: The characteristics of $\mathrm{PM}_{2.5}$ in Beijing, China, Atmos. Environ., 35, 4959-4970, https://doi.org/10.1016/S1352-2310(01)00301-6, 2001.

Huang, W., Saathoff, H., Shen, X., Ramisetty, R., Leisner, T., and Mohr, C.: Chemical Characterization of Highly Functionalized Organonitrates Contributing to Night-Time Organic Aerosol Mass Loadings and Particle Growth, Environ. Sci. Technol., 53, 1165-1174, https://doi.org/10.1021/acs.est.8b05826, 2019.

Kanawade, V. P., Tripathi, S. N., Chakraborty, A., and Yu, H.: Chemical Characterization of Sub-micron Aerosols during New Particle Formation in an Urban Atmosphere, Aerosol Air Qual. Res., 20, 1294-1305, https://doi.org/10.4209/aaqr.2019.04.0196, 2020.

Kerminen, V., Chen, X., Vakkari, V., Petäjä, T., Kulmala, M., and Bianchi, F.: Atmospheric new particle formation and growth: review of field observations, Environ. Res. Lett., 13, 103003, https://doi.org/10.1088/1748-9326/aadf3c, 2018.

Knote, C., Hodzic, A., Jimenez, J. L., Volkamer, R., Orlando, J. J., Baidar, S., Brioude, J., Fast, J., Gentner, D. R., Goldstein, A. H., Hayes, P. L., Knighton, W. B., Oetjen, H., Setyan, A., Stark, H., Thalman, R., Tyndall, G., Washenfelder, R., Waxman, E., and Zhang, Q.: Simulation of semi-explicit mechanisms of SOA formation from glyoxal in aerosol in a 3-D model, Atmos. Chem. Phys., 14, 6213-6239, https://doi.org/10.5194/acp14-6213-2014, 2014.

Kuang, C., McMurry, P. H., and McCormick, A. V.: Determination of cloud condensation nuclei production from measured new particle formation events, Geophys. Res. Lett., 36, L09822, https://doi.org/10.1029/2009GL037584, 2009.

Kulmala, M., Dal Maso, M., Mäkelä, J. M., Pirjola, L., Väkevä, M., Aalto P., Miikkulainen, P., Hämeri, K., and O'dowd, C. D.: On the formation, growth and composition of nucleation mode particles, Tellus B, 53, 479-490, https://doi.org/10.1034/j.16000889.2001.530411.x, 2001.
Kulmala, M., Vehkamäki, H., Petäjä, T., Dal Maso, M., Lauri, A., Kerminen, V. M., Birmili, W., and McMurry, P. H.: Formation and growth rates of ultrafine atmospheric particles: a review of observations, J. Aerosol Sci., 35, 143-176, https://doi.org/10.1016/j.jaerosci.2003.10.003, 2004.

Kulmala, M. and Kerminen, V.: On the formation and growth of atmospheric nanoparticles, Atmos. Res., 90, 132-150, https://doi.org/10.1016/j.atmosres.2008.01.005, 2008.

Kulmala, M., Petäjä, T., Nieminen, T., Sipilä, M., Manninen, H. E., Lehtipalo, K., Dao Maso, M., Aalto, P. P., Junninen, H., Paasonen, P., Riipinen, I., Lehtinen, K. E. J., Laaksonen, A., and Kerminen, V-M.: Measurement of the nucleation of atmospheric aerosol particles, Nat. Protoc., 7, 1651-1667, https://doi.org/10.1038/nprot.2012.091, 2012.

Kulmala, M., Petäjä, T., Kerminen, V.-M., Kujansuu, J., Ruuskanen, T., Ding, A., Nie, W., Hu, M., Wang, Z., Wu, Z., Wang, L., and Worsnop, D. R.: On secondary new particle formation in China, Front. Environ. Sci. Eng., 10, 8, https://doi.org/10.1007/s11783016-0850-1, 2016.

Laakso, L., Merikanto, J., Vakkari, V., Laakso, H., Kulmala, M., Molefe, M., Kgabi, N., Mabaso, D., Carslaw, K. S., Spracklen, D. V., Lee, L. A., Reddington, C. L., and Kerminen, V.M.: Boundary layer nucleation as a source of new $\mathrm{CCN}$ in savannah environment, Atmos. Chem. Phys., 13, 1957-1972, https://doi.org/10.5194/acp-13-1957-2013, 2013.

Lee, B. H., Mohr, C., Lopez-Hilfiker, F. D., Lutz, A., Hallquist, M., Lee, L., Romer, P., Cohen, R. C., Iyer, S., Kurtén, T., Hu, W., Day, D. A., Campuzano-Jost, P., Jimenez, J. L., Xu, L., Ng, N. L., Guo, H., Weber, R. J., Wild, R. J., Brown, S. S., Koss, A., de Gouw, J., Olson, K., Goldstein, A. H., Seco, R., Kim, S., McAvey, K., Shepson, P. B., Starn, T., Baumann, K., Edgerton, E. S., Liu, J., Shilling, J. E., Miller, D. O., Brune, W., Schobesberger, S., D'Ambro, E. L., and Thornton, J. A.: Highly functionalized organic nitrates in the southeast United States: Contribution to secondary organic aerosol and reactive nitrogen budgets, P. Natl. Acad. Sci. USA, 113, 1516-1521, https://doi.org/10.1073/pnas.1508108113, 2016.

Lee, S., Gordon, H., Yu, H., Lehtipalo, K., Haley, R., Li, Y., and Zhang, R.: New Particle Formation in the Atmosphere: From Molecular Clusters to Global Climate, J. Geophys. Res.-Atmos., 124, 7098-7146, https://doi.org/10.1029/2018JD029356, 2019.

Levy, M. E., Zhang, R., Khalizov, A. F., Zheng, J., Collins, D. R., Glen, C. R., Wang, Y., Yu, X., Luke, W., Jayne, J. T., and Olaguer, E.: Measurements of submicron aerosols in Houston, Texas during the 2009 SHARP field campaign, J. Geophys. Res.-Atmos., 118, 10518-10534, https://doi.org/10.1002/jgrd.50785, 2013.

Li, J., Yin, Y., Li, P., Li, Z., Li, R., Cribb, M., Dong, Z., Zhang, F., Li, J., Ren, G., Jin, L., and Li, Y.: Aircraft measurements of the vertical distribution and activation property of aerosol particles over the Loess Plateau in China, Atmos. Res., 155, 73-86, https://doi.org/10.1016/j.atmosres.2014.12.004, 2015.

Liu, X., Zhang, Y., Cheng, S., Xing, J., Zhang, Q., Streets, D. G., Jang, C., Wang, W., and Hao, J.: Understanding of regional air pollution over China using CMAQ, part I performance evaluation and seasonal variation, Atmos. Environ., 44, 2415-2426, https://doi.org/10.1016/j.atmosenv.2010.03.035, 2010a.

Liu, X., Zhang, Y., Xing, J., Zhang, Q., Wang, K., Streets, D. G., Jang, C., Wang, W., and Hao, J.: Understanding of regional air pollution over China using CMAQ, part II. Pro- 
cess analysis and sensitivity of ozone and particulate matter to precursor emissions, Atmos. Environ., 44, 3719-3727, https://doi.org/10.1016/j.atmosenv.2010.03.036, $2010 \mathrm{~b}$.

Liu, X. H., Zhu, Y. J., Zheng, M., Gao, H. W., and Yao, X. H.: Production and growth of new particles during two cruise campaigns in the marginal seas of China, Atmos. Chem. Phys., 14, 7941-7951, https://doi.org/10.5194/acp-14-7941-2014, 2014.

Lu, Y., Yan, C., Fu, Y., Chen, Y., Liu, Y., Yang, G., Wang, Y., Bianchi, F., Chu, B., Zhou, Y., Yin, R., Baalbaki, R., Garmash, O., Deng, C., Wang, W., Liu, Y., Petäjä, T., Kerminen, V.-M., Jiang, J., Kulmala, M., and Wang, L.: A proxy for atmospheric daytime gaseous sulfuric acid concentration in urban Beijing, Atmos. Chem. Phys., 19, 1971-1983, https://doi.org/10.5194/acp19-1971-2019, 2019.

Ma, N., Zhao, C., Tao, J., Wu, Z., Kecorius, S., Wang, Z., Größ, J., Liu, H., Bian, Y., Kuang, Y., Teich, M., Spindler, G., Müller, K., van Pinxteren, D., Herrmann, H., Hu, M., and Wiedensohler, A.: Variation of $\mathrm{CCN}$ activity during new particle formation events in the North China Plain, Atmos. Chem. Phys., 16, 8593-8607, https://doi.org/10.5194/acp-16-8593-2016, 2016.

Man, H., Zhu, Y., Ji, F., Yao, X., Lau, N. T., Li, Y., Lee, B. P., and Chan, C. K.: Comparison of Daytime and Nighttime New Particle Growth at the HKUST Supersite in Hong Kong, Environ. Sci. Technol., 49, 7170-7178, https://doi.org/10.1021/acs.est.5b02143, 2015.

Matsui, H., Koike, M., Kondo, Y., Takegawa, N., Wiedensohler, A., Fast, J. D., and Zaveri, R. A.: Impact of new particle formation on the concentrations of aerosols and cloud condensation nuclei around beijing, J. Geophys. Res.-Atmos., 116, D19208, https://doi.org/10.1029/2011JD016025, 2011.

Nieminen, T., Lehtinen, K. E. J., and Kulmala, M.: Sub-10 nm particle growth by vapor condensation - effects of vapor molecule size and particle thermal speed, Atmos. Chem. Phys., 10, 97739779, https://doi.org/10.5194/acp-10-9773-2010, 2010.

Petäjä, T., Mauldin, III, R. L., Kosciuch, E., McGrath, J., Nieminen, T., Paasonen, P., Boy, M., Adamov, A., Kotiaho, T., and Kulmala, M.: Sulfuric acid and $\mathrm{OH}$ concentrations in a boreal forest site, Atmos. Chem. Phys., 9, 7435-7448, https://doi.org/10.5194/acp9-7435-2009, 2009.

Qi, J., Liu, X., Yao, X., Zhang, R., Chen, X., Lin, X., Gao, H., and Liu, R.: The concentration, source and deposition flux of ammonium and nitrate in atmospheric particles during dust events at a coastal site in northern China, Atmos. Chem. Phys., 18, 571-586, https://doi.org/10.5194/acp-18-571-2018, 2018.

Quan, J., Liu, Y., Liu, Q., Jia, X., Li, X., Gao, Y., Ding, D., Li, J., and Wang, Z.: Anthropogenic pollution elevates the peak height of new particle formation from planetary boundary layer to lower free troposphere, Geophys. Res. Lett., 44, 7537-7543, https://doi.org/10.1002/2017GL074553, 2017.

Riipinen, I., Pierce, J. R., Yli-Juuti, T., Nieminen, T., Häkkinen, S., Ehn, M., Junninen, H., Lehtipalo, K., Petäjä, T., Slowik, J., Chang, R., Shantz, N. C., Abbatt, J., Leaitch, W. R., Kerminen, V.-M., Worsnop, D. R., Pandis, S. N., Donahue, N. M., and Kulmala, M.: Organic condensation: a vital link connecting aerosol formation to cloud condensation nuclei (CCN) concentrations, Atmos. Chem. Phys., 11, 3865-3878, https://doi.org/10.5194/acp-11-3865-2011, 2011.

Rodelas, R. R., Chakraborty, A., Perdrix, E., Tison, E., and Riffault, V.: Real-time assessment of wintertime or- ganic aerosol characteristics and sources at a suburban site in northern France, Atmos. Environ., 203, 48-61, https://doi.org/10.1016/j.atmosenv.2019.01.035, 2019.

Rose, C., Sellegri, K., Moreno, I., Velarde, F., Ramonet, M., Weinhold, K., Krejci, R., Andrade, M., Wiedensohler, A., Ginot, P., and Laj, P.: CCN production by new particle formation in the free troposphere, Atmos. Chem. Phys., 17, 1529-1541, https://doi.org/10.5194/acp-17-1529-2017, 2017.

Sabaliauskas, K., Jeong, C., Yao, X., Jun, Y., Jadidian, P., and Evans, G. J.: Five-year roadside measurements of ultrafine particles in a major Canadian city, Atmos. Environ., 49, 245-256, https://doi.org/10.1016/j.atmosenv.2011.11.052, 2012.

Seinfeld, J. H. and Pandis, S. N.: Atmospheric chemistry and 115 physics: from air pollution to climate change, John Wiley \& Sons, New York, 2012.

US-EPA: Guidance on the Use of Models and Other Analyses for Demonstrating Attainment of Air Quality Goals for Ozone, $\mathrm{PM}_{2.5}$, and Regional Haze, EPA-454/B-407-002, 2007.

Vu, T. V., Delgado-Saborit, J. M., and Harrison, R. M.: A review of hygroscopic growth factors of submicron aerosols from different sources and its implication for calculation of lung deposition efficiency of ambient aerosols, Air Qual. Atmos. Health., 8, 429440, https://doi.org/10.1007/s11869-015-0365-0, 2015.

Wang, M., Kong, W., Marten, R., He, X., Chen, D., Pfeifer, J., Heitto, A., Kontkanen, J., Dada, L., Kürten, A., Yli-Juuti, T., Manninen, H., Amanatidis, S., Amorim, A., Baalbaki, R., Baccarini, A., Bell, D., Bertozzi, B., Bräkling, S., Brilke, S., Murillo, U. C., Chiu, R., Chu, B., De Menezes, L.-P., Duplissy, J., Finkenzeller, H., Carracedo, L. G., Granzin, M., Guida, R., Hansel, A., Hofbauer, V., Krechmer, J., Lehtipalo, K., Lamkaddam, H., Lampimäki, M., Lee, C. P., Makhmutov, V., Marie, G., Mathot, S., Mauldin, R. L., Mentler, B., Müller, T., Onnela, A., Partoll, E., Petäjä, T., Philippov, M., Pospisilova, V., Ranjithkumar, A., Rissanen, M., Rörup, B., Scholz, W., Shen, J., Simon, M., Sipilä, M., Steiner, G., Stolzenburg, D., Tham, Y. J., Tomé, A., Wagner, A. C., Wang, D. S., Wang, Y., Weber, S. K., Winkler, P. M., Wlasits, P. J., Wu, Y., Xiao, M., Ye, Q., ZaunerWieczorek, M., Zhou, X., Volkamer, R., Riipinen, I., Dommen, J., Curtius, J., Baltensperger, U., Kulmala, M., Worsnop, D. R., Kirkby, J., Seinfeld, J. H., El-Haddad, I., Flagan, R. C., and Donahue, N. M.: Rapid growth of new atmospheric particles by nitric acid and ammonia condensation, Nature, 581, 184-189, https://doi.org/10.1038/s41586-020-2270-4, 2020.

Wang, Z. B., Hu, M., Wu, Z. J., Yue, D. L., He, L. Y., Huang, X. F., Liu, X. G., and Wiedensohler, A.: Long-term measurements of particle number size distributions and the relationships with air mass history and source apportionment in the summer of Beijing, Atmos. Chem. Phys., 13, 10159-10170, https://doi.org/10.5194/acp-13-10159-2013, 2013.

Wang, Z. B., Hu, M., Pei, X. Y., Zhang, R. Y., Paasonen, P., Zheng, J., Yue, D. L., Wu, Z. J., Boy, M., and Wiedensohler, A.: Connection of organics to atmospheric new particle formation and growth at an urban site of Beijing, Atmos. Environ., 103, 7-17, https://doi.org/10.1016/j.atmosenv.2014.11.069, 2015.

Wehner, B., Wiedensohler, A., Tuch, T. M., Wu, Z. J., Hu, M., Slanina, J., and Kiang, C. S.: Variability of the aerosol number size distribution in Beijing, China: New particle formation, dust storms, and high continental background, Geophys. Res. Lett., 31, L22108, https://doi.org/10.1029/2004GL021596, 2004. 
Whitby, K. T.: The physical characteristics of sulfur aerosols, Atmos. Environ., 12, 135-159, https://doi.org/10.1016/B978-0-08022932-4.50018-5, 1978.

Wiedensohler, A., Cheng, Y. F., Nowak, A., Wehner, B., Achtert, P., Berghof, M., Birmili, W., Wu Z. J., Hu, M., Zhu, T., Takegawa, N., Kita, K., Kondo, Y., Lou, S. R., Hofzumahaus, A., Holland, F., Wahner, A., Gunthe, S. S., Rose, D., Su, H., and Pöschl, U.: Rapid aerosol particle growth and increase of cloud condensation nucleus activity by secondary aerosol formation and condensation: A case study for regional air pollution in northeastern china, J. Geophys. Res., 114, D00G08, https://doi.org/10.1029/2008JD010884, 2009.

Wu, Z., Hu, M., Liu, S., Wehner, B., Bauer, S., Ma ßling, A., Wiedensohler, A., Petäjä, T., Dal Maso, M., and Kulmala, M.: New particle formation in Beijing, China: Statistical analysis of a 1-year data set, J. Geophys. Res., 112, D09209, https://doi.org/10.1029/2006JD007406, 2007.

Wu, Z. J., Zheng, J., Shang, D. J., Du, Z. F., Wu, Y. S., Zeng, L. M., Wiedensohler, A., and Hu, M.: Particle hygroscopicity and its link to chemical composition in the urban atmosphere of Beijing, China, during summertime, Atmos. Chem. Phys., 16, 11231138, https://doi.org/10.5194/acp-16-1123-2016, 2016.

Xu, W. Q., Han, T. T., Du, W., Wang, Q. Q., Chen, C., Zhang, Y. J., Li, J., Fu, P. Q., Wang, Z. F., Worsnop, D. R., and Sun, Y. L.: Effects of aqueous-phase and photochemical processing on secondary organic aerosol formation and evolution in Beijing, China, Environ. Sci. Technol., 51, 762-770, https://doi.org/10.1021/acs.est.6b04498, 2017.

Yao, X., Choi, M. Y., Lau, N. T., Lau, A. P. S., Chan, C. K., and Fang, M.: Growth and Shrinkage of New Particles in the Atmosphere in Hong Kong, Aerosol Sci. Tech., 44, 639-650, https://doi.org/10.1080/02786826.2010.482576, 2010.

Yao, X., Lau, N. T., Fang, M., and Chan, C. K.: RealTime Observation of the Transformation of Ultrafine Atmospheric Particle Modes, Aerosol Sci. Tech., 39, 831-841, https://doi.org/10.1080/02786820500295248, 2005.

Yu, F. and Luo, G.: Simulation of particle size distribution with a global aerosol model: contribution of nucleation to aerosol and CCN number concentrations, Atmos. Chem. Phys., 9, 76917710, https://doi.org/10.5194/acp-9-7691-2009, 2009.

Yu, H., Ortega, J., Smith, J. N., Guenther, A. B., Kanawade, V. P., You, Y., Liu, Y., Hosman, K., Karl, T., Seco, R., Geron, C., Pallardy, S. G., Gu, L., Mikkilä, J., and Lee, S. H.: New Particle Formation and Growth in an Isoprene-Dominated Ozark Forest: From Sub-5nm to CCN-Active Sizes, Aerosol Sci. Technol., 48, 1285-1298, 2014.
Yu, H., Ren, L., Huang, X., Xie, M., He, J., and Xiao, H.: Iodine speciation and size distribution in ambient aerosols at a coastal new particle formation hotspot in China, Atmos. Chem. Phys., 19, 4025-4039, https://doi.org/10.5194/acp-19-4025-2019, 2019.

Yue, D. L., Hu, M., Zhang, R. Y., Wang, Z. B., Zheng, J., Wu, Z. J., Wiedensohler, A., He, L. Y., Huang, X. F., and Zhu, T.: The roles of sulfuric acid in new particle formation and growth in the mega-city of Beijing, Atmos. Chem. Phys., 10, 4953-4960, https://doi.org/10.5194/acp-10-4953-2010, 2010.

Yue, D. L., Hu, M., Zhang, R. Y., Wu, Z. J., Su, H., Wang, Z. B., Peng, J., He, L., Huang, X., Gong, Y., and Wiedensohler, A.: Potential contribution of new particle formation to cloud condensation nuclei in Beijing, Atmos. Environ., 45, 6070-6077, https://doi.org/10.1016/j.atmosenv.2011.07.037, 2011.

Zhang, Q., Xue, D., Liu, X. H., Gong, X., and Gao, H. W.: Process analysis of $\mathrm{PM}_{2.5}$ pollution events in a coastal city of China using CMAQ, J. Environ. Sci., 79, 225-238, 2019.

Zhang, R., Khalizov, A., Wang, L., Hu, M., and Xu, W.: Nucleation and Growth of Nanoparticles in the Atmosphere, Chem. Rev., 112, 1957-2011, https://doi.org/10.1021/cr2001756, 2012.

Zhang, R., Wang, G., Guo, S., Zamora, M. L., Ying, Q., Lin, Y., Wang, W., Hu, M., and Wang, Y.: Formation of Urban Fine Particulate Matter, Chem. Rev., 115, 3803-3855, https://doi.org/10.1021/acs.chemrev.5b00067, 2015.

Zhang, Y. M., Zhang, X. Y., Sun, J. Y., Hu, G. Y., Shen, X. J., Wang, Y. Q., Wang, T. T., Wang, D. Z., and Zhao, Y.: Chemical composition and mass size distribution of $\mathrm{PM}_{1}$ at an elevated site in central east China, Atmos. Chem. Phys., 14, 12237-12249, https://doi.org/10.5194/acp-14-12237-2014, 2014.

Zhu, Y., Sabaliauskas, K., Liu, X., Meng, H., Gao, H., Jeong, C., Evans, G. J., and Yao, X.: Comparative analysis of new particle formation events in less and severely polluted urban atmosphere, Atmos. Environ., 98, 655-664, https://doi.org/10.1016/j.atmosenv.2014.09.043, 2014.

Zhu, Y., Yan, C., Zhang, R., Wang, Z., Zheng, M., Gao, H., Gao, Y., and Yao, X.: Simultaneous measurements of new particle formation at $1 \mathrm{~s}$ time resolution at a street site and a rooftop site, Atmos. Chem. Phys., 17, 9469-9484, https://doi.org/10.5194/acp17-9469-2017, 2017.

Zhu, Y., Li, K., Shen, Y., Gao, Y., Liu, X., Yu, Y., Gao, H., and Yao, X.: New particle formation in the marine atmosphere during seven cruise campaigns, Atmos. Chem. Phys., 19, 89-113, https://doi.org/10.5194/acp-19-89-2019, 2019.

Zimmerman, N., Jeong, C., Wang, J. M., Ramos, M., Wallace, J. S., and Evans, G. J.: A source-independent empirical correction procedure for the fast mobility and engine exhaust particle sizers, Atmos. Environ., 100, 178-184, https://doi.org/10.1016/j.atmosenv.2014.10.054, 2015. 